\title{
Pilar de Goiás: a vila entre a memória, a história e a materialidade ${ }^{1}$
}

\author{
Rodrigo da Silva ${ }^{2}$ \\ Carlos Eduardo França de Oliveira ${ }^{3}$
}

RESUMO: Este artigo busca compreender a interface estabelecida entre a arqueologia histórica, a história e a política nacional de proteção do patrimônio histórico, artístico, arquitetônico e arqueológico - através do instrumento legal de tombamento - materializada no caso da cidade de Pilar de Goiás, no estado de Goiás. Essa proteção, iniciada na década de 1950, ocorrida de modo conceitual e tecnicamente frágil, acarretou uma série de problemas e desafios para os campos da história e da arqueologia, sobretudo no tocante à preservação desse mesmo patrimônio nacional. A vila mineradora setecentista passou por inúmeras "corridas do ouro" seguidas de abandono das lavras e decréscimo populacional ltoda vez que se esgotavam as fontes do metal). Tal processo, iniciado em período colonial e ainda em andamento, favoreceu a construção de uma série de memórias que complicam a interpretação mais objetiva do perfil dessa vila colonial. No presente trabalho buscamos compreender esses processos e como as pesquisas científicas - e mesmo as políticas para o patrimônio - informaram-se na memória, criando um cenário algo confuso a respeito do passado colonial de Pilar de Goiás. Diante disso, e recorrendo aos documentos históricos e à historiografia, propomos uma interpretação a respeito de Pilar de Goiás, fundamentada em uma sociedade muito plástica, plural e de economia multifacetada. Procedimento que, distante das interpretações grandiosas e excessivamente fundamentadas na busca daquilo que seria uma "sociedade mineradora", auxilia-nos a compreender os processos envolvidos na ocupação colonial e na construção de redes de comércio, de trânsito e de urbanização da parcela central da Colônia.

PALAVRAS-CHAVE: Pilar de Goiás. Brasil colônia. Mineração. Arqueologia histórica. História.

ABSTRACT: This article seeks to understand the interface established between historical archeology, history and the national policy of protection of historical, artistic, architectural and archaeological heritage - through the legal instrument of tipping - materialized in the case of the city of Pilar de Goiás, in the state of Goiás. This protection, begun in the 1950s, occurred in a conceptually and technically fragile way, led to a series of problems and challenges in the fields of history and archeology, especially in the preservation of this same national patrimony. The

\begin{abstract}
1. Este trabalho é resultante das pesquisas realizadas no âmbito do projeto de identificação, proteção e divulgação do conjunto de bens culturais (arqueológicos, históricos, imateriais) de Pilar de Goiás/GO em 2010. O projeto era coordenado pelo dr. Paulo Zanettini, sócio-diretor da Zanettini Arqueologia.

2. Pós-doutorando no Museu Paulista da USP (MP/USP) / Universidade de São Paulo. E-mail: <rodrigo.arqueo@ usp.br>.

3. Doutor pelo Programa de Pós-Graduação em História Social da Faculdade de Filosofia, Letras e Ciências Humanas (FFLCH) / Universidade de São Paulo. E-mail: <carlosoliveira@usp.br>.
\end{abstract}


4. Em 1937 o governo federal criou o Serviço do Patrimônio Histórico e Artístico Nacional através da Lei $\mathrm{n}$. 378 , de 13 de janeiro, estando subordinado então ao Ministério da Educação e Saúde. Em 2 de janeiro de 1946, o Decreto-lei n. 8534 alterou a denominação do órgão para Diretoria do Patrimônio Histórico e Artístico Nacional. Em 1953, o Ministério da Educação e Saúde foi desmembrado em duas partes, o Ministério da Saúde e o Ministério da Educação e Cultura (MEC), o qual manteve em sua estrutura o DPHAN. Em 1970, finalmente, o Decreto $\mathrm{n}$. 66.967, de 27 de julho, alterou a denominação do órgão para Instituto do Patrimônio Histórico e Artístico Nacional, mantendo-o na estrutura do MEC.

5. Processo (1952, ofício de 28/3/1952).

6. Processo (1952, ofício de 29/3/1952). eighteenth-century mining town went through innumerable "gold bullfights" followed by mining abandonment and population decline (every time the metal fountains were exhausted). This process, initiated in the colonial period and still in progress, favored the construction of a series of memories that complicate the more objective interpretation of the profile of this colonial village. In the present work we seek to understand these processes and how the scientific researches - and even the policies for the patrimony - were informed in the memory, creating a somewhat confusing scenario regarding the colonial past of Pilar de Goiás. The historiography, we propose an interpretation about Pilar de Goiás based on a very plastic society, plural and multifaceted economy. This procedure, far from the grandiose and excessively grounded interpretations of the search for what would be a "mining society", helps us to understand the processes involved in colonial occupation and the construction of networks of commerce, transit, and urbanization of the central portion of the Colony.

KEYWORDS: Pilar de Goiás. Colonial Brazil. Mining. Historical Archaeology. History

tombamento de Pilar de Goiás e a preservação de uma (in)certa memória

Em 1952 o Departamento de Patrimônio Histórico e Artístico Nacional, o DPHAN, ${ }^{4}$ encaminhou solicitação de abertura de processo de tombamento da antiga vila de Pilar de Goiás, documento produzido pelo arquiteto Edgar Jacinto da Silva, então chefe da Seção de Artes. $\bigcirc$ argumento invocado para o desencadeamento da ação dizia que edificações de "valor artístico" e "documentário" estavam sendo demolidas para dar lugar a outras destoantes do núcleo original. $\bigcirc$ tombamento, assim, acautelaria "possíveis mutilações que seriam irreparáveis", as quais poderiam desfigurar o traçado primitivo da vila mineradora do século XVIII. Jacinto da Silva garantiu, ainda, que o DPHAN estava empenhado na restauração da igreja da Nossa Senhora das Mercês, da Casa das Rótulas, àquela altura doada à União para dela ser feita um museu, e da Casa do Oratório. ${ }^{5}$

A proposta foi aprovada pela direção do próprio DPHAN, de modo que, em fins do mês de março de 1952, o então diretor Rodrigo de Melo Franco de Andrade encaminhou um ofício ao prefeito de Itapaci - Manoel de Oliveira Penna - comunicando-the a inscrição do conjunto arquitetônico e urbanístico da sede do distrito de Pilar de Goiás no Livro do Tombo Histórico e no Livro do Tombo das Belas-Artes, de acordo com os fins estabelecidos pelo Decreto-Lei $n^{\circ}$ 25, de 30 de novembro de 1937. Ao documento foi anexada uma planta da área a ser tombada. ${ }^{6}$

A resposta do prefeito dava mostras de que o tombamento de Pilar de Goiás não era consensual, sobretudo pelo poder público local. Segundo Oliveira 
Penna, a prefeitura de Itapaci havia iniciado um "serviço de desentulhamento de uma área de terreno localizada na zona urbana de Pilar", onde não existia "nenhuma construção", havendo apenas "uns restos de taipa e ruínas que muito enfeiavam a cidade". Os muros demolidos - "longe de constituírem obras de arte" - eram um "amontoado de pedras que muito enfeiavam o panorama urbanístico da cidade" e de construção "relativamente recente". ?

mais provável é que a preocupação da prefeitura de Itapaci fosse menos arquitetônica/urbanística do que política e econômica. Para Oliveira Penna a população do distrito de Pilar desejava a elevação do distrito à categoria de município, o que poderia ser barrado pelo tombamento, em virtude das restrições à abertura de novas ruas e edificações. Por fim, apontou para a questão de que o mapa anexo ao ofício remetido pelo DPHAN era imperfeito e não condizente com o traçado da cidade.

DPHAN discordou das alegações do prefeito de Itapaci. Em correspondência a Rodrigo de Melo Franco, Jacinto da Silva afirmou que os ditos "restos de taipa" e "ruínas" compunham justamente um dos trechos de maior importância dentro do conjunto urbanístico de Pilar, e que a remoção destes "alteraria substancialmente o caráter documentário" a que se propunha o tombamento. Ademais, os resquícios de muros que estavam sendo demolidos eram feitos de lajes de pedra seca, de característica local e integrada à fisionomia urbana de Pilar. No que tange à futura implantação de novas ruas e edificações, o arquiteto sugeriu a criação de uma zona fora da área demarcada a fim de atender às demandas da população. Por fim, a respeito do mapa da cidade, ponderou que esse seria substituído por outro mais preciso, de natureza aerofotográfica, num momento oportuno. ${ }^{8}$

Em nova missiva à prefeitura de Itapaci, Rodrigo de Melo Franco endossou as ponderações de Jacinto da Silva e acrescentou que o tombamento não impediria que Pilar fosse elevada à categoria de município, uma vez que cidades como Ouro Preto, Mariana, Diamantina e Alcântara foram tombadas sem que isto "Ihes afetasse a significação econômica, social ou política". 9

Tais esclarecimentos não suprimiram o desacordo entre o DPHAN e a prefeitura de Itapaci. Em carta ao prefeito Oliveira Penna datada de junho de 1953, Jacinto da Silva expôs seu desagrado para com aquela prefeitura, que ainda não se pronunciara em definitivo sobre o assunto. $\bigcirc$ próprio governo do estado de Goiás, segundo o arquiteto, tinha interesse no tombamento de Pilar, a fim de acelerar a elevação daquele distrito à condição de município, na Assembleia Legislativa goiana. Desse modo, Jacinto da Silva solicitava a cooperação do município, evitando, assim, o tombamento compulsório, que segundo ele consistia num recurso "desaconselhável em se tratando de órgãos da administração pública". ${ }^{10}$

Apesar da pressão vinda do Rio de Janeiro, o prefeito de Itapaci protelou novamente sua deliberação sobre o caso. Alegando estar a Assembleia Legislativa de Goiás ocupada com o projeto de municipalização de Pilar, o que de fato
7. Processo (1952, ofício de 15/4/1952).

8. Processo (1952, ofício de $15 / 5 / 1952)$.

9. Processo (1952, ofício de 26/5/1952).

10. Processo (1952, ofício de $15 / 6 / 1953)$. 
11. Processo (1952, ofício de $16 / 6 / 1953$ )

12. Processo (1952, ofício de $1 \% 10 / 1956)$.

13. Processo (1952, ofício de $18 / 8 / 1965)$ concretizou-se com a lei de 5 de outubro de 1953, Oliveira Penna solicitou um "prazo razoável" para dar uma resposta definitiva, evitando assim qualquer choque entre o texto do tombamento e o da nova lei. $O$ prefeito disse não ser contrário ao tombamento, porém acreditava que esse deveria ser feito levando em conta a dinâmica do poder público local. ${ }^{.1}$

A documentação referente ao processo de tombamento de Pilar de Goiás não dispõe de documentos que atestem se o procedimento legal foi feito de maneira compulsória ou com a anuência das autoridades locais. $\bigcirc$ fato é que, em 25 de março de 1954, Rodrigo de Melo Franco e Andrade expediu à recéminstalada prefeitura de Pilar de Goiás a inscrição do conjunto arquitetônico e paisagístico referido nos Livros do Tombo Histórico e no Livro do Tombo das BelasArtes, sob os n’s 302 e 414, respectivamente. Entre 1955 e 1956, o DPHAN aprofundou os estudos de demarcação da área tombada.

Nesse contexto, marcado pelo desencontro entre o poder local e o DPHAN, é notável que a ausência de estudos específicos, sobretudo de história e arquitetura, fez do tombamento de Pilar algo frágil já de início, um processo despido de informações que o tornassem consistente. Independentemente do valor histórico e artístico dos vestígios da antiga vila do século XVIII - os dois eixos que embasaram o tombamento -, a falta de uma argumentação contundente possibilitou seu contínuo questionamento por parte das administrações municipais.

Há um vazio documental de cerca de dez anos no mencionado processo de tombamento, entre os estudos de demarcação da área tombada e as novas contestações por parte do poder municipal, já nos anos sessenta. Em 1965, numa inspeção de rotina feita no local, o arquiteto Fernando Machado Leal comunicou ao DPHAN que as autoridades municipais pilarenses afirmavam desconhecer o tombamento. ${ }^{12}$ Após novas explicações por parte do DPHAN, o prefeito de Pilar encaminhou ao Rio de Janeiro um documento - o qual contava com assinaturas de supostos moradores - solicitando que a área tombada ficasse circunscrita "tão somente aos prédios da cadeia pública local e da chamada casa da União", considerados os "únicos prédios antigos ou históricos" de Pilar. O documento também reconhecia como área passível de tombamento o chamado campo da "cavalhada", local onde era realizada essa manifestação. A justificativa do pedido recaía, novamente, sobre o crescimento econômico e demográfico do município:

Pilar de Goiás, no momento, atravessa uma fase de progresso, e muitos de seus habitantes tencionam construir prédios modernos, embora modestos, e muitos já estão com material comprado, aguardando permissão para construir prédios decentes, de acordo com a evolução já acentuada nesta próspera região. E a prefeitura já construiu aqui prédios do Fórum, Grupo Escolar, que são construções condignas, fora outros melhoramentos, inclusive cemitério. ${ }^{13}$

A solicitação foi indeferida pelo DPHAN. Este assinalou, em primeiro lugar, que de acordo com o decreto-lei de 28 de novembro de 1941, apenas o presidente teria atribuições para chancelar ou retificar tombamentos. Além disso, o 
DPHAN não julgou procedente o pedido, posto que a redução da área tombada acarretaria uma descaracterização do conjunto em questão. Novas casas e ruas poderiam ser construídas, portanto, fora do perímetro tombado. Por outro lado, dentro da área protegida, o DPHAN se dispunha a acompanhar a reforma da fachada das casas dos moradores que assim desejassem. ${ }^{14}$

$\bigcirc$ caráter lacunar da documentação referente ao processo torna difícil investigar a relação entre os poderes federal e local para além dos pontos de vista mais imediatos a respeito do tombamento nas décadas de cinquenta e sessenta: se para o município ele significava o engessamento das políticas públicas, um entrave ao desenvolvimento do município, para o DPHAN se configurava como a solução para a preservação do patrimônio ali existente. Nessa falta de entendimento entre as duas esferas, bem como de uma aparente ausência de comunicação com a sociedade, está a origem dos problemas relativos à preservação do patrimônio de Pilar de Goiás.

Vale lembrar que o próprio DPHAN, criado poucos anos antes sob o nome de Serviço de Patrimônio Histórico e Artístico Nacional (SPHAN), embrião do atual Iphan, demorou longo período para configurar suas práticas, métodos, procedimentos, não apenas aqueles de caráter mais técnico - encaminhamentos legais, de delimitação, registro, identificação, proteção, restauro etc. -, mas, talvez ainda mais grave, os de caráter político e social. As primeiras décadas de ação no campo da preservação do patrimônio cultural brasileiro foram marcadas por constante tensão entre os atores e contínuas disputas; parte dos processos de tombamento e das medidas de preservação adotadas nesse período redundaram em problemas diversos, alguns dos quais ainda estão postos.

Nesse sentido Pilar de Goiás não constitui excepcionalidade, outros processos de tombamento nos primeiros anos do SPHAN/DPHAN eram de igual fragilidade e abundam registros de conflitos de diversas ordens em São Paulo, Mariana, Ouro Preto, Rio de Janeiro, Sete Povos das Missões e diversas outras localidades que tiveram seus conjuntos urbanos, ou bens arquitetônicos, tombados, ou demolidos, na época.

Pilar de Goiás ainda padeceu, nas décadas seguintes ao seu tombamento, da ausência de protagonismo no cenário das chamadas "cidades históricas" em Goiás, onde prevaleceram Vila Boa e Pirenópolis, esta originalmente denominada Meia Ponte. Pouco ou quase nada teria ocorrido, inclusive para investigar a história da vila e compreender sua materialidade, não fosse sua sina atrelada a sucessivos surtos de mineração de ouro, os quais se arrastam aos dias atuais.

Novo surto aurífero, velhos problemas em Pilar de Goiás

Pilar de Goiás, como veremos melhor adiante, surgiu em função da mineração de ouro no século XVIII, mas diferentemente de outras vilas e cidades
14. Processo (1952, ofício de 17/9/1965). 
nascidas do mesmo processo, teve um desenvolvimento rápido, limitado e interrompido abruptamente, dadas as reduzidas reservas do metal. Em linhas gerais podemos dizer que, desde o descobrimento do ouro na região, Pilar de Goiás passou por sucessivas ondas de mineração desencadeadas pela descoberta de novos depósitos do metal ou pela retomada de lavras antigas suportadas por novas tecnologias, permitindo o reaproveitamento de áreas tidas como esgotadas ou de rejeitos deixados por explorações anteriores. Esses surtos se repetiram com frequência, inclusive ao longo do século XX. Nos anos de 1990 desencadeou-se o mais recente desses processos.

Diferentemente dos surtos anteriores, o processo desencadeado nos anos 1990 estava subsidiado em tecnologia moderna e de caráter industrial; em outras palavras, enquanto os movimentos anteriores foram marcados por pequenas "corridas do ouro" tocadas por levas de garimpeiros independentes, a pesquisa e - projeto de extração desencadeados no final do século XX tinham a sua frente uma grande empresa mineradora, com vasto maquinário e grande contingente de trabalhadores. Da mesma forma, enquanto o processo de extração desde o século XVIII era marcado pela faiscação e extração de outro de aluvião, o processo contemporâneo implicava abertura de minas de subsolo, com galerias e enormes tanques de flotação.

A instalação de tal processo levava a vários problemas imediatos para a preservação do patrimônio cultural em Pilar de Goiás: em primeiro lugar, a abertura da mina, distante apenas 100 metros do perímetro tombado, representava risco físico ao patrimônio, fosse pela movimentação de máquinas, fosse pela construção de galerias subterrâneas. Em segundo lugar, a instalação da planta mineradora punha em risco todo um universo minerador não mapeado, deixado de escanteio pelo processo malconduzido de tombamento da cidade. Vale lembrar que os primeiros anos do Serviço de Patrimônio foram marcados por uma imensa hegemonia da arquitetura, com várias clivagens que hoje nos parecem estranhas e insuficientes. Essa insistência na arquitetura e no urbanismo, a prevalência do barroco mineiro como parâmetro para as artes, a pouca compreensão ou interesse pela cultura material de caráter mais banal e cotidiano levaram ao desprezo de parte substancial das estruturas que compunham o cotidiano dessa vila mineradora e que, ora abandonadas há séculos, compunham sua própria história e trajetória. Em termos práticos, isso significa que todas as antigas lavras, acampamentos, áreas de descarte, de moradia dos garimpeiros, não estavam mapeados, delimitados ou protegidos por qualquer instrumento legal. Por fim, a chegada de centenas de trabalhadores temporários em função da implantação da mina representava riscos materiais e sociais a Pilar de Goiás.

Instado a se manifestar diante do fato de haver tamanha movimentação em cidade com patrimônio histórico tombado pela União, o lphan solicitou a retomada das pesquisas a respeito da história, do patrimônio cultural tangível e intangível, da arquitetura, da arqueologia e, por fim, do próprio processo de tombamento da década de 1950. O município, mais uma vez, diante da 
oportunidade do desenvolvimento econômico, novamente se posicionou contrário a novas medidas protecionistas ou qualquer ampliação/revisão dos perímetros originais de proteção. Em suma, Pilar de Goiás revivia com maior intensidade as mesmas disputas estabelecidas nas décadas de 1950 e 1960.

Pilar de Goiás: "auge" e "decadência" ou uma sociedade multifacetada?

Da vila do século XVIII pouco restou no conjunto tombado originalmente pelo DPHAN: a Casa da Câmara e Cadeia, a Casa de Intendência, a Casa da Princesa, a Casa das Rótulas, as Igrejas de Nossa Senhora das Mercês e a da padroeira, Nossa Senhora do Pilar, o chafariz de São José, a Gruta dos Escravos. $\bigcirc$ pouco que restou encontrava-se seriamente comprometido no início dos anos 2000 e, nos anos seguintes, algumas intervenções emergenciais foram realizadas; vale dizer que parte substancial das intervenções foi realizada antes de qualquer pesquisa histórica sistemática, traço recorrente no lphan apesar das décadas de experiência. Outras tantas intervenções, realizadas sem qualquer acompanhamento, no decorrer do século XX também concorreram para descaracterizar e, mais ainda, criar simulacros do suposto passado da vila. Como veremos adiante, isso compõe um problema não menor para a preservação e gestão do patrimônio cultural em geral e, especificamente, em Pilar de Goiás.

As implicações e os entrelaçamentos entre a história e a memória foram vastamente estudados e discutidos tanto pela própria história quanto pela psicologia. ${ }^{15}$ Os complexos percursos da construção, apropriação, transmissão e ressignificação das memórias, individuais ou coletivas, implicam o emprego de inúmeras ferramentas e artifícios. Muitas vezes, quando tratamos da memória acabamos por desmaterializá-la, como se seus processos fossem absolutamente mentais e prescindissem da materialidade. Essa discussão, que para pesquisadores de museus históricos é, se não óbvia, basal, acaba por ser negligenciada muitas vezes nos estudos e ações que envolvem o patrimônio, sobretudo aquele de caráter arquitetônico e/ou arqueológico. ${ }^{16}$ Quando muito a memória é invocada como um bem, algo a ser "preservado", "mantido", "protegido", "transmitido", o que nesse discurso legitima as ações no e com o patrimônio cultural.

$\bigcirc$ fato é que, na maioria absoluta das vezes, geralmente quando se trata do patrimônio arquitetônico ou histórico, é a memória que opera a mediação entre as pessoas e a materialidade; não é a história a realizar a primeira abordagem entre a sociedade e seus marcos. Daí Pierre Nora insistir na existência de "lugares de memória", 17 definição que, hoje, já sofreu inúmeras revisões e críticas, mas cuja reflexão continua válida.

Pilar de Goiás não foge a essa descrição geral. A relação imediata da população local com o patrimônio e a materialidade da cidade, e mesmo dos visitantes, pesquisadores ou não, se dá pelos processos da memória, não da
15. Le Goff (1996), Ricoeur (2007), Ecléa Bosi (2012).

16. Oliveira (2009), Guimarães; Ramos (2010), Poulot (2013).

17. Nora (1984). 
história, da arquitetura, da arqueologia, embora em alguns casos haja nitidamente uma contaminação das dimensões, como veremos.

Em 2010, em um relatório preliminar a respeito de Pilar de Goiás enviado ao Iphan pela equipe responsável pelas novas pesquisas históricas/ arqueológicas/patrimoniais na área histórica, a cidade foi assim descrita:

Por fim, o bandeirante fundou o Arraial de Pilar no ano de 1741 e virou guarda-mor de suas minas. $\bigcirc$ ato da fundação do povoado foi a edificação no local da igreja de Nossa Senhora do Pilar, da qual era devoto, denominação dada ao arraial nascente, que em poucos anos tornou-se cenário de pompa e riquezas, com frequentes visitas de fidalgos do Reino. A cidade nasceu rica e chegou a ter quatro igrejas e nove mil escravos. Com um desenvolvimento surpreendente, decorrente da imensa quantidade de ouro extraído na região, o arraial tornou-se freguesia, em 1751, passando a "julgado" em 1809. Erguida no ano em que o arraial se tornou freguesia, a igreja encantava viajantes e bandeirantes que saíam de São Paulo, atravessavam Goiás até o Mato Grosso em busca de ouro. "A matriz é rica, bela, espaçosa com sete altares. Tem peças de prata, lâmpada de extraordinária grandeza e custódia dourada. É das mais bem-dotadas da província", escreveu o brigadeiro Cunha Matos, que, em 1823, fez detalhado levantamento de todos os povoados goianos. Em Pilar, conheceu as quatro igrejas. Uma dos brancos, uma dos negros, uma dos índios e uma dos mestiços. Hoje só a Matriz e a igreja de Nossa Senhora das Mercês estão em pé. Ao lado da Matriz, há três imensos sinos, o maior pesando 900 quilos. Segundo a tradição foram fundidos pelos escravos e tiveram adicionado ouro à liga para ampliar o som de suas batidas. "Esses sinos são das cousas mais notáveis da Capitania de Goyás", escreveu em 1821, o Bispo da Província, Luiz Antonio da Silva e Souza. O ouro era extraído nas encostas através do desbaste ou abertura de dutos, além de bateado nas barrancas dos cursos-d'água. Nos primeiros gloriosos anos do garimpo, tiravam em média 100 arrobas de ouro anuais. Por Decreto ou Resolução Provincial de 11 de novembro de 1831, passou à categoria de Vila, instalando-se em 7 de janeiro de 1833, com o topônimo simplificado para "Pilar". ${ }^{18}$

É de certo modo impressionante que o Iphan, instituto responsável pela proteção do patrimônio cultural brasileiro, tenha acatado tal relatório. Das 275 páginas que o compõem, menos de dez são reservadas à história de Pilar de Goiás. Havemos de convir que foram os aspectos históricos da cidade - expressos em sua materialidade - que levaram ao seu reconhecimento e (suposta?) proteção pelo órgão, o que acentua o estranhamento com tal displicência no tratamento da questão. Podemos aventar inúmeras possibilidades para a gênese do problema - a predominância que a arquitetura e, mais recentemente, a arqueologia précolonial tomaram no Iphan, o relativo distanciamento dos historiadores e da disciplina com as questões do patrimônio -, mas a responsabilidade do órgão não pode se escorar nelas.

A ideia central do relatório, e da percepção do Iphan, a respeito de Pilar de Goiás está fundamentada no binômio apogeu/decadência, estrutura que pouco ou nenhum sentido faz quando não qualificada, contextualizada e cotejada aos olhos da História tal como a entendemos e praticamos contemporaneamente.

Assim como as demais áreas do conhecimento, as ciências humanas e, nesse caso, a História constroem seu discurso a partir de conceitos e categorias. $\mathrm{Na}$ busca pela cientificidade do seu ofício, o historiador teve que se adequar, entre 
outras, a três exigências básicas: o enquadramento de sua pesquisa em um paradigma definido; o uso de hipóteses tecnicamente balizadas; e a definição de um sistema conceitual. Dessa forma, a criação de um aparato teórico pelo historiador faz-se necessária na medida em que a apreensão da realidade concreta, impossível de ser feita em sua totalidade, necessita de um recorte epistemológico que the torne inteligível. Daí a importância dos conceitos que, ora criticados, ora defendidos, mostram-se essenciais no âmbito do debate sobre o fazer histórico. ${ }^{19}$

Dois dos conceitos mais complexos utilizados pela historiografia são os de apogeu e decadência. Alguns autores discorreram sobre o emprego ou não de termos que detenham esse significado, ${ }^{20}$ mas a verdade é que ambos ainda são muito utilizados pela historiografia. Pouco discutidos em termos teóricos, esses conceitos oferecem algumas dificuldades para a análise histórica. Em primeiro lugar, porque carreiam a ideia de que o desenvolvimento, entendido como algo eminentemente econômico, é algo sempre possível e desejável, uma vez que o mundo está supostamente em constante progresso. Em segundo lugar, ambos trazem à tona a não menos problemática concepção de ciclo, que tende a enrijecer os fenômenos históricos e interpretá-los à luz de um único paradigma explicativo, marcadamente etapista, ignorando assim que as sociedades se constituem a partir de diversas camadas da vida humana, sejam elas atreladas à economia, à política e à cultura.

Tais concepções permeiam boa parte da historiografia que trata sobre as sociedades mineradoras do período colonial da América portuguesa. ${ }^{21} \mathrm{Em}$ grande medida isso se explica pelo fato de que as jazidas minerais um dia esgotamse, ou diminuem sensivelmente sua oferta de metais preciosos, e, portanto, a exploração de um minério passa por um processo natural de auge e declínio. Mas o que ocorre, entretanto, é uma confusão entre o decaimento da exploração mineral e o da sociedade em que ela se verifica. Em outros termos, significa assumir que, a priori, toda e qualquer sociedade mineradora passará necessariamente por um período de apogeu e decadência.

Interpretações desse tipo obscurecem o entendimento sobre determinada sociedade, não apenas por se aterem a uma lógica desenvolvimentista e economicista da análise histórica, mas também porque elas criam, invariavelmente, narrativas mitificadoras repletas de exageros e imprecisões. Historiadores e, sobretudo, memorialistas acabam distorcendo seu objeto de estudo em busca de estabelecer uma polarização de períodos que, em princípio, já é artificial. De um lado cria-se uma "era de ouro" grandiosa, rica e próspera; de outro, por oposição, forja-se um período de inexpressividade, carência de recursos e falta de perspectiva.

A cidade e a memória: da materialidade à memória e vice-versa

No excerto do relatório apresentado ao Iphan, além da constituição do binômio apogeu/decadência, aflora a ênfase no caráter supostamente suntuoso de Pilar de Goiás quando de sua fundação e imediatamente depois. Alguns
19. Marrou (1978).

20. Veyne (1976), Le Goff (1996).

21. Graça Filho (2002). 
22. Bueno (2011), Silva (2016).

23. Kok (2004).

24. Araujo (1998), Borrego (2006).

25. Renfrew; Bahn (2008), Prous (1992), Warnier (1999).

26. Pesez (2003), Warnier (1999), Roche (2000). números são lançados mais com o objetivo de impressionar o leitor do que de dimensionar a vida material da cidade: um sino de 900 quilos, cerca de 9.000 escravos, a velocidade da evolução administrativa da localidade, a quantidade de arrobas de ouro extraídas. Junto com os números seguem informações qualitativas: a recepção de inúmeros fidalgos do Reino, uma casa construída para receber a visita de Princesa Isabel, o dourado da ornamentação da Matriz.

Tal discurso, aos olhos do historiador, acostumado com o perfil das cidades coloniais da América Portuguesa, surpreende. Tal grandiosidade teria passado tão despercebida por nossa historiografia, mesmo a dedicada a essa parcela do território?

De fato, existem imensas lacunas sobre nossa história, e outro tanto igualmente imenso de revisões à espera para serem operadas. Os estudos recentes a respeito da ocupação do território, ${ }^{22}$ do desbravamento dos sertões, ${ }^{23}$ da intensidade e da velocidade do surgimento do urbano e das redes mercantis ${ }^{24}$ apresentam um cenário promissor e empolgante sobre a Colônia e o Império. Contudo, são raríssimas as revisões dessa natureza, de ocupações de tal magnitude sobejamente ignoradas pela historiografia.

Nesse aspecto é importante perguntar: quais processos operaram para que tal narrativa prosperasse? Qual a origem de tal interpretação? No que ela se fundamenta?

A arqueologia é uma área do conhecimento interdisciplinar, a qual envolve matérias tão distintas quanto a botânica e a história, ou a geologia e a antropologia. Dado que seus objetos de estudo, os seres humanos e suas culturas, são os mesmos da história e da antropologia, restam como distintivos seus métodos de pesquisa. Sem querer estabelecer qualquer polêmica mais ampla, ou uma infrutífera discussão sobre os limites e limitações das ciências, o fato é que a investigação acurada da cultura material está entre as prerrogativas da arqueologia. Esse é um elemento inescapável de sua especificidade, seja como documento, seja como método. ${ }^{25}$

Ora, como vimos, a cultura material não está isenta dos filtros e camadas que afetam todas as ciências sociais. Os resultados químicos, geomorfológicos, biológicos das investigações estão sujeitos a uma interpretação cujo objetivo final é a construção de uma narrativa a respeito de uma cultura. Não se trata da constituição de um novo polímero ou de um sequenciamento genético. Para isso, e por isso, existem vastas discussões metodológicas e teóricas. ${ }^{26}$

Quando a arqueologia se estabelece, então, no campo da história há uma segunda ordem de problemas, pois, diferentemente da pré-história, a história está constantemente entrelaçada na memória e a construção das narrativas possui igualmente sua historicidade.

De algumas décadas para cá, certas correntes da arqueologia passaram a insistir na necessidade em se "dar voz" às populações locais, a inseritas no processo de construção das interpretações, envolvê-las nas pesquisas e na tomada de decisões a respeito do patrimônio cultural. Tal aproximação, no concernente às 
decisões sobre o futuro do patrimônio, sua apropriação, uso e democratização, é absolutamente bem-vinda; contudo, há certa desconfiança quanto à inserção das populações locais nos processos de pesquisa na mesma chave cognitiva, epistemológica que os cientistas. Se não por qualquer outro óbice, pelo fato de o uso e a relação dos povos com o patrimônio serem completamente outros daqueles estabelecidos pelas ciências.

Mas a arqueologia histórica se informa nas populações locais. Fá-lo, e o fez, em Pilar de Goiás sem mediar os inúmeros discursos, narrativas e significações, sobretudo aqueles operados pela memória.

As oscilações econômicas e demográficas na trajetória de Pilar de Goiás talvez tenham colaborado para a construção de uma memória coletiva fundamentada no binômio apogeu/decadência, bem como da ideia de uma "idade de ouro" da localidade. Talvez haja algo de contaminação a partir da própria narrativa a respeito da trajetória das cidades do ouro das Minas Gerais, a qual também estava, em meados do século XX, fundamentada ainda na ideia de apogeu/glória e decadência. Não devemos esquecer que parte substancial das ações iniciais do SPHAN (depois alterado para DPHAN e, finalmente, Iphan) circundaram o universo das cidades mineiras e, principalmente, da estética colonial/barroca. Ocorre que as pesquisas a respeito do passado colonial mineiro se desdobraram, complexificaram, relativizaram muitos dos pressupostos então estabelecidos ${ }^{27}$ nas décadas seguintes, o que não ocorreu com a mesma intensidade com os estudos de várias outras regiões brasileiras, como Goiás e, ainda mais, Pilar de Goiás. É possível que resida aí, também, parte dessa perpetuação de uma memória fundamentada na percepção de uma suntuosidade perdida. Não é raro ouvir dos moradores locais as mesmas descrições inseridas no relatório recepcionado pelo Iphan, com ênfase nos mesmos detalhes e números.

$\bigcirc$ mapeamento das áreas de mineração, circundantes à cidade, executado pela equipe de arqueólogos identificou não apenas uma extensa área, mas uma quantidade significativa de refugos da atividade mineradora, cascalho abandonado e ora retrabalhado com técnicas de mineração modernas (RELATÓRIO..., 2010). A extensão da área e o volume de material impressionaram a equipe de pesquisa arqueológica e, automaticamente, foram transferidos como comprovação da memória coletiva local.

É algo preocupante o fato de que as equipes de arqueólogos que trabalham em contextos históricos conheçam de modo tão rudimentar a historiografia relativa aos seus locais de pesquisa. A ausência de um acompanhamento das pesquisas mais próximo e não apenas circunstancial por historiadores vai produzindo um saber de segunda categoria, desperdiçando esforços e recursos tão escassos às pesquisas a respeito do patrimônio cultural brasileiro.

A surpresa dos arqueólogos na identificação das áreas envoltórias de Pilar de Goiás envolvidas nas lides de mineração era uma derivação de uma série de desconhecimentos: do quanto é rápida e intensa a atividade mineradora, mesmo em tempos de Colônia. Do quanto um escravo é capaz de produzir
27. Souza (2004), Furtado (1999), Maxwell (2010). 
mediante o regime de trabalho ao qual está submetido, ainda mais quando, no caso da mineração, criam-se estruturas de incentivo fundamentadas no sucesso da atividade. Da variedade de estratégias empregadas para a movimentação de terra e de suas forças, como deslocamento de cursos-d'água, represamentos. Por fim, da desconsideração do fato de que Pilar de Goiás passou por diversos surtos de mineração, os quais ocorreram mais ou menos sobre as mesmas áreas, criando um acúmulo brutal de trabalho desde o século XVIII. Em suma, preocupados em mapear, escavar, delimitar, proteger áreas, as lides arqueológicas abandonaram uma de suas tarefas fundamentais, que é a de interpretar a cultura material.

A pergunta, que possui diversos níveis de operação, é: o quanto a história, de fato, pode, conjuntamente com os estudos de cultura material, orientarnos em uma interpretação mais correta e lúcida do passado e, especificamente, do patrimônio histórico?

Longe de, no âmbito deste artigo, querer solucionar tal gama de problemas, podemos empreender uma breve incursão no que a historiografia brasileira pode nos dizer a respeito de Pilar de Goiás e do ambiente que compôs a sua criação e nas décadas seguintes.

A vila e a história: (des)caminhos historiográficos

Em fins da década de 1880, muito antes de Rodrigo Melo Franco de Andrade protagonizar o tombamento de Pilar de Goiás, seu avô, o senador Virgílio Alvim de Melo Franco, percorreu o interior da então província de Goiás e deixou o seguinte testemunho sobre a vila goiana:

[...] o mau clima, a miséria geral, as correias de selvagens que costumam invadir a vila, a extinção do ouro e outras causas afugentaram todos os habitantes e deve-se presumir que em pouco até se ignore o lugar que existiu, como já aconteceu [...] com outros extintos [...] por sua posição geográfica ao norte da capital de Goiás, da qual dista 33 léguas, pelos maus caminhos, pela falta absoluta de recursos, insalubridade e perigos de ataque dos selvagens, e diversas outras causas, pode-se dizer que é um lugar inabitável $[\ldots]^{28}$

A percepção negativa de Melo Franco em nada se distancia dos relatos produzidos sobre Pilar e, de forma mais abrangente, sobre Goiás ao longo do século XIX, o que nos coloca de antemão um problema incontornável. Historiar o processo de ocupação e desenvolvimento de Pilar de Goiás é um exercício que resvala, inevitavelmente, numa teia de narrativas constituídas ao longo do tempo sobre a história de Goiás setecentista, período que conforme acima mencionado foi, e em certa medida ainda é, acionado e interpretado pela chave "augedecadência". Procedimento que turva tanto o entendimento sobre a dinâmica histórica da região e sua inserção no quadro mais geral da colonização portuguesa na América, como a respeito da construção da memória coletiva que serve de matéria-prima/justificativa para os órgãos de preservação patrimonial em suas 
políticas de intervenção. ${ }^{29}$ Torna-se necessário, portanto, fazer uma rápida incursão na bibliografia que estabeleceu parte do alicerce interpretativo da história goiana a fim de se compreender melhor o lugar de Pilar de Goiás nesse movimento.

Datam do início do século XIX as primeiras narrativas históricas sobre Goiás. Redigido pelo padre mineiro Luiz Antônio da Silva e Souza (1764-1840), - texto Memória sobre o descobrimento, governo, população e cousas mais notáveis da capitania de Goyaz (1814) é um marco memorial da produção histórica goiana. Traça em linhas gerais as investidas das primeiras bandeiras que penetraram o sertão habitado pelos índios goyazes, bem como a consequente empreitada de Bartolomeu Bueno da Silva em busca de ouro e o estabelecimento dos primeiros núcleos populacionais goianos. ${ }^{30}$ Narrativa que em muito se assemelha às memórias setecentistas produzidas sob encomenda da Coroa portuguesa e que ganhariam fôlego renovado após a chegada da família real ao Brasil, a obra de Silva e Souza lançou a semente de um vigoroso olhar que ganharia corpo posteriormente, qual seja, a ideia de modelar a história de Goiás a partir do binômio esplendor-decadência da mineração, inaugurando uma série de relatos de forte orientação teleológica que enxergariam na penúria oitocentista o destino inevitável de uma sociedade que, embora pujante e próspera, sucumbiu ao caráter predatório e errático da economia mineradora. Assim, mais do que uma simples oposição entre era dourada e presente decadente, os relatos gestados no século XIX disseminariam uma dicotomia em torno de um passado ao mesmo tempo glorioso e responsável por seu futuro problemático.

Em Corografia Histórica de Goiás (1824-25), Raimundo José da Cunha Matos (1776-1839) recompôs a história de Goiás tendo como pano de fundo o processo de ruralização e empobrecimento goiano decorrentes da crise aurífera, deixando ao leitor uma avaliação reticente sobre as consequências da ocupação da região. A obra, que só viria a público cinquenta anos depois nas páginas do Instituto Histórico e Geográfico Brasileiro, do qual o militar e historiador luso-brasileiro fora integrante de prestígio, corroborava com a maioria das corografias oitocentistas ao mirar a história como magistra vitae, tratando o passado aurífero como lição a ser tirada pelos homens do presente para suas orientações futuras. Nesse sentido, Goiás surgia como projeto, um vir-a-ser objeto da ação do Estado imperial. ${ }^{31}$

José Martins Pereira de Alencastre (1831-1871), autor de Anais da Província de Goiás (1863), deu prosseguimento às abordagens anteriores, porém enfatizou um ponto pouco explorado até então: o fardo da herança colonial. ${ }^{32}$ É em Alencastre que se pode observar em cores vivas uma crítica direta à administração lusa, que, no afã pelo enriquecimento rápido, tomou medidas que se chocavam com os interesses dos súditos radicados nas minas goianas. Proibições a atividades diversas - abertura de estradas, navegação, iniciativas industriais alternativas à mineração - teriam contribuído para a estagnação econômica da região, historicamente refém da cobiça da Coroa portuguesa. Presidente da província de Goiás entre 1861 e 1862, Alencastre
29. Borges (1987).

30. Souza (1998).

31. Mattos (1979).

32. Alencastre (1979). 
33. Sandes; Arrais (2013, p. 852-53). Sobre as crônicas de viagem na Goiás oitocentista, ver Doles; Nunes (1992).

34. Sandes; Arrais (2013, p. 859). Essa nova tendência já vinha sendo esboçada em alguns textos do final do século XIX. Breve reflexão sobre o meio mais eficaz de se remediar a decadência da capitania de Goiaz (1892).

35. São o caso das obras, por exemplo, de Americano do Brasil, Zoroastro Artiaga, Henrique Silva, Ofélia Sócrates Monteiro, Sebastião Fleury Curado, Jaime Câmara. Silva (2015).

36. Silva (2015). alçou para primeiro plano um julgamento de ordem moral sobre o processo de colonização goiano.

Esse aprisionamento discursivo em torno do contraste presente-passado teve eco em outros circuitos letrados do século XIX. Como observaram Arrais e Sandes, tal perspectiva também é encontrada, em maior ou menor grau, nos relatos de cronistas e nos relatórios de presidentes de província:

Saint Hilaire (1 8 19) fala em "grande decadência" e "profunda apatia em que estão imersos" os habitantes de Goiás, Rodrigues Jardim (1835) julga as estradas da província como "sofríveis", assim como descreveu Camargo Fleury (1837) "em péssimo estado", Pohl (1817) refere-se aos "caminhos esburacados" e Castelnau (1843) ao "mau estado dos caminhos". Foi também Rodrigues Jardim quem caracterizou a dinâmica social regional: "o ocio e a falta de política em hum Paiz onde se pode viver sem trabaliar tem também concorrido para a diminuição da abundância, que nelle se disfructava", no que é acompanhado por Pohl "enquanto tem uns vinténs no bolso, não mexem com as mãos". D'Alincourt (1818) descreve os habitantes de Goiás como "dominados pela preguiça e demasiadamente entregues aos prazeres sexuais e bem diferentes são as causas que os têm conduzido a tão deplorável estado"; e para Taunay (1 876) "a população [...] vive vida lânguida e desanimada". Mesmo os escritos de Couto Magalhães (1 863), que procuram fugir às lamentações e aos pedidos de auxílio, comuns à maioria dos relatórios provinciais, não deixam de atestar o contraste entre o potencial econômico não explorado e a degeneração moral dos habitantes de Goiás: "aqui a vida se escoa gemendo constantemente", sentencia o jovem presidente da província. ${ }^{33}$

No início do século XX surgiram trabalhos dotados de um discurso que, sem abandonar de todo a herança oitocentista, comprometia-se a dar maior visibilidade ao estado de Goiás dentro da recém-instituída República. Nos artigos veiculados pela revista Informação Goyana, no Rio de Janeiro de 1917 a 1935, fica evidente a preocupação em expor ao universo do mercado - potencial econômico regional, lançando para o futuro um possível novo "ciclo" de prosperidade. ${ }^{34}$ Além disso, nas décadas de 1930, 1940 e 1950 circularam textos empenhados em construir uma pretensa identidade goiana, missão levada adiante por memorialistas, advogados, médicos e historiadores amadores cujas narrativas, embora qualitativamente heterogêneas, convergiam em certa medida por tecerem relatos quase sempre estruturados em uma história política factual, oficialesca e apologética, fazendo do trato das fontes tarefa pouco analítica, quando não um elemento comprobatório de discursos previamente concebidos. ${ }^{35}$ Muitas dessas personagens eram filiadas ao Instituto Histórico e Geográfico de Goiás (1933) e/ou à Academia Goiana de Letras (1939), instituições que buscavam no passado elementos de uma "goianidade" ainda por se descobrir. ${ }^{36}$

Esse quadro começaria a ser alterado a partir da década de 1960, sobretudo de 1970, com a criação das Universidades Católica e Federal de Goiás, que possibilitaram a oferta do curso superior de História e a produção de um conhecimento reconhecidamente científico. Uma nova fisionomia historiográfica apareceria com a criação do Programa de Mestrado em História da Universidade 
Federal de Goiás, em 1972, e com os trabalhos de Luís Palacín, cuja tese de livredocência defendida na mesma instituição, Goiás 1722/1822. Estrutura e conjuntura numa capitania de Minas, representou uma virada teórico-metodológica nos tratos temático e documental referentes à história goiana. ${ }^{37}$ Aos poucos firmouse a consciência da necessidade de estabelecer estudos que, além de romperem com o viés anterior, lançassem as bases para novas linhas de pesquisa. ${ }^{38}$ Nos últimos anos a produção historiográfica goiana vem se caracterizando pela diversidade de temas e abordagens, porém, dadas a tradição e a difusão das narrativas constituídas até meados do século XX, a desconstrução desses modelos ainda é uma tarefa a ser enfrentada pelos pesquisadores.

As linhas acima fornecem algumas pistas sobre como se processou a inserção de Pilar de Goiás na bibliografia referente à história goiana. Indícios que nos levam a crer que a história pilarense enquanto produto memorialísticohistoriográfico foi contaminada pelo paradigma apologético e/ou decadentista. Porque refém de uma axiologia aplicada por memorialistas e historiadores que the imputaram um papel menor no contexto da exploração aurífera goiana, Pilar de Goiás foi alvo de apenas breves comentários daqueles que sobre ela debruçaram, isso já durante os séculos XVIII e XIX. Sem o mesmo peso político-econômico de uma Vila Boa ou Meia Ponte, mais ainda assim a elas comparada direta ou indiretamente, Pilar surge, à primeira vista, como um núcleo de expressividade reduzida na Goiás setecentista. A questão torna-se mais complexa porque via de regra não é difícil encontrar fontes de época que atestem um suposto momento de decadência, o que no caso da cidade de Pilar de Goiás pode ser notado a partir de documentos oficiais e relatos de viagem produzidos no século XIX.

Os textos de época de que se têm conhecimento sobre Pilar são escassos, sobretudo os setecentistas, a exemplo do Diário da Visita Geral da Capitania de Goiás (1773),39 manuscrito que relata a viagem feita pelo governador de Goiás José de Almeida de Vasconcellos de Soveral e Carvalho e que pouco trata do arraial. Meio século depois, seriam publicadas as Memórias Históricas do Rio de Janeiro e das províncias anexas à jurisdição do Vice-Rei do Estado do Brasil ( 1 820), ${ }^{40}$ estudo financiando pela Corte joanina e executado pelo monsenhor José de Souza Azevedo Pizarro e Araújo. As Memórias não configuram um estudo específico sobre Goiás, porém oferecem informações pontuais de Pilar, como dados populacionais, geográficos, econômicos e administrativos, que encontram similar em Cunha Matos e Alencastre, obras cujo teor já foi esboçado acima. A produção posterior que trata de Pilar não altera esse quadro geral. Afora relatos de cunho memorialístico ${ }^{41}$ e estudos isolados sobre a arquitetura ${ }^{42}$ e a cultura locais, ${ }^{43}$ existem pesquisas ainda em curso sobre - patrimônio arqueológico e cultural pilarense em decorrência dos empreendimentos mineradores mais recentes na região. ${ }^{44}$

Estaria então justificado o uso da relação "auge-decadência"? Cremos que não, e nesse caso por três motivos centrais: quanto aos documentos oficiais, diferentemente do que podem sugerir a um primeiro olhar, eles serviam muito mais
37. Palacín (1972).

38. Chaul (1997, p. 45-46).

39. Diário (1773).

40. Araújo (1820).

41. Castro (1996).

42. Dubugras (1965).

43. Lima (1990).

44. Wichers; Lussim; Dionizio (2015). 
45. Medicci (2010).

46. Palacín; Moraes (1994, p. 28-29). como estratégia de luta política do que relatos meramente técnicos e isentos de interesses. Falar de um passado glorioso e frente a um presente decadente constituía um artifício retórico de grande eficácia para justificar atos e projetos políticos, privilegiar grupos em detrimento de outros. ${ }^{45}$ Quanto aos chamados "viajantes", categoria equívoca que tende a homogeneizar homens de distintas formações e experiências pessoais, pode-se dizer que suas narrativas estão carregadas de elementos que vão desde o contato com a memória local escrita e oral até a comparação, muitas vezes impressionista, entre localidades muito distintas, o que acaba gerando ponderações contrastantes, como é possível notar em obras de autores como François de Castelnau. Por fim, há uma diversidade de fontes espalhadas por diferentes arquivos que indicam um quadro mais matizado da história de Pilar, que por sinal ainda carece de um estudo mais circunstanciado.

Não se trata, para o caso de Pilar de Goiás, de negar certa pujança econômica trazida pelo ouro em meados do XVIII, tampouco de refutar o decréscimo populacional ocorrido ao longo do século XIX. A questão é que, voluntariamente ou não, historiadores, arqueólogos e memorialistas reproduziram amiúde as impressões legadas pelos agentes históricos, sedimentando verdades de difícil desconstrução, tão arraigadas que ficaram no discurso científico e no imaginário popular. É aí que ideias como "auge" e "decadência" ganham força e se perpetuam sem uma avaliação crítica sobre por que e como foram criadas, ou até mesmo a respeito dos motivos pelos quais esses termos, não obstante extremos, ainda seduzem estudiosos de diversas áreas.

É preciso compreender, portanto, que a história não se processa de forma linear e evolutiva, mas sim de maneira fragmentada, cheia de idas e vindas, apropriações e reapropriações, e que é justamente a sua escrita pelo historiador que the confere um caráter mais ou menos homogêneo. Além disso, faz-se necessário ter cautela para não tomar as vozes dos protagonistas do passado como se fossem indícios precisos da realidade histórica à qual se referem, a fim de não cair nos caminhos sinuosos e traiçoeiros da memória.

Um breve panorama histórico de Pilar de Goiás

Muito embora em fins do século XVII já circulassem entre habitantes da Capitania de São Paulo informações sobre a existência de ouro no então chamado "sertão de Goiás", a ocupação e exploração do território goiano só ganhou força no transcurso da década de 1720, após o sucesso da campanha exploratória dos sertanistas Bartolomeu Bueno da Silva, João Leite da Silva Ortiz e Bartolomeu Pais de Abreu. Em 1727, em decorrência do garimpo desenvolvido ao longo do rio Vermelho, erigiu-se ali o arraial de N. Senhora de Santana (futura Vila Boa), cujo cargo de superintendente das minas foi entregue ao próprio Bueno da Silva, que continuou a comandar expedições para o interior goiano em busca de novas riquezas minerais. ${ }^{46}$ 
A proliferação da notícia sobre a descoberta de ouro em Goiás promoveu um aceleramento na ocupação das áreas situadas no Caminho de Goiás, rota que ligava a vila de São Paulo às jazidas goianas e que já era parcialmente conhecida por sertanistas antes mesmo do surto aurífero goiano. Em decorrência do aumento da circulação de contingentes populacionais diversos, as administrações local e metropolitana determinaram algumas medidas voltadas para uma ocupação da região que atendessem, na medida do possível, tanto aos interesses dos colonos como aos da Coroa portuguesa. Por outro lado, com a justificativa de estabelecer pousos e paragens para os viajantes e tropas - o que de certo modo aumentaria a receita da Coroa, em decorrência da cobrança do real dízimo -, diversos sertanistas solicitaram sesmarias ao longo trajeto. Já em 1726, Bueno da Silva e Silva Ortiz receberam uma sesmaria ao norte do rio Pardo, além da concessão para a exploração das passagens dos rios Iguatibaia, Jaguary, Pardo, Grande, das Velhas, Parnahyba, Guacurumbá, Meia Ponte e dos Pasmados. ${ }^{47}$

As descobertas auríferas se sucedem e, nos anos seguintes, novos arrais surgiram nas proximidades de Vila Boa, como Anta, Ferreiro, Ouro Fino e Santa Rita (1727). Mais ao sul fundaram-se Santa Cruz (1729) e Meia Ponte (1727) e, ao norte, Água-Quente (1732), Crixás (1734), Traíras (1735) e S. José do Tocantins e Cachoeira (1736). Estima-se que em 1730 as minas goianas já haviam atraído mais de 20 mil almas, o que colocou de vez Goiás na malha administrativa da colonização portuguesa. ${ }^{48}$ Ao final da década de 1730 são descobertos depósitos de metais na região montanhosa localizada entre o Tocantins e a Bahia: São Luís (Natividade) em 1734, São Félix (1736), Pontal, Porto Real (1738), Arraias, Cavalcanti (1740). E entre 1740 e 1750, Carmo (1746), Santa Luzia, Conceição, Bonfim, Caldas e Cocai (1749). De modo geral, a exploração do ouro de Goiás dividiu-se entre as duas regiões que compunham a Capitania, a norte e a sul. Na porção meridional, as lavras situavam-se nas altas cabeceiras do Tocantins e Araguaia, e nas dos afluentes da margem direita do Parnaíba. De menor proporção, a exploração de ouro levada a cabo na região setentrional concentrava-se nos distritos de São José, Santa Rita, Cachoeira e Conceição. ${ }^{49}$

$\bigcirc$ histórico de ocupação de Pilar inscreve-se no contexto exploratório das lavras de Crixás, cujo volume de ouro extraído nos primeiros anos acabou transformando o arraial, ao lado de Meia Ponte, como sede de uma das duas comissárias da intendência de Vila Boa. Em 1741, em suas andanças pela região de Vila Boa e Traíras, na margem ocidental do rio Maranhão, João Godoy Pinto da Silveira descobriu novas minas, no início batizadas de Papoãn, mas que em poucos anos receberam o nome de Pilar. Situadas aproximadamente 10 léguas de Crixás, Papoãn e suas cercanias eram habitadas pelos povos Curuxás, também conhecidos por Kirixás, e Canoeiros. ${ }^{50}$

A constante afluência de mineiros tornou necessária a fundação de um arraial. No local foi erigida uma Capela dedicada à Nossa Senhora do Pilar. Pela Provisão de 3 de maio de 1751 foi-the destinada uma parte do distrito da freguesia de Nossa Senhora da Conceição de Crixás. Anos depois, pelo Alvará de 9 de
47. Bacellar; Brioschi (1999).

48. Palacín; Moraes (1994, p. 28-29).

49. Simonsen (1978, p. 281).

50. Alencastre (1979, p. 108-109). 
51. Araújo (1820, p. 79).

52. Registro (1732-1795, Cx. 984, documentos diversos).

53. Palacín (1972), Chaul (1997). janeiro de 1755, passou a gozar da graça de igreja paroquial perpétua e, havendo-a paroquiado na sua origem o padre Anastácio Pereira, mediante Provisão de 3 de maio de 1751, sucedeu de propriedade o padre Antônio Fraga de Meirelles, por apresentado à 12 de janeiro de 1755, e confirmado à 21 de maio seguinte. Por volta de 1758, tornou-se assento da Comarca Eclesiástica. ${ }^{51}$

Entre as décadas de 1750 e 1790, houve um número significativo de pedidos de sesmarias por mineiros, roceiros e criadores de gado para a região de Pilar (rio Peixe; ribeirões da Posse, São Patrício, São Jerônimo, São Pedro, Vermelho e Ponte Alta, Bacalhau; e córregos de "Passatrês" e Monjolol, Amaro Leite, Guarinos, especialmente nas cercanias dos caminhos que interligavam essas localidades. Mas ao contrário do que se pode imaginar num primeiro momento, os requerentes das sesmarias não eram indivíduos estáticos que restringiram seus domínios e permanência ao arraial de Pilar. Conscientes de que a mineração não constituía uma atividade inesgotável, famílias solicitavam terras em outras paragens, seja na região norte de Goiás, hoje Tocantins, seja no caminho para Vila Boa, com vistas a desdobrarem seus empreendimentos. ${ }^{52}$

É difícil precisar para Pilar, assim como o é para o caso das Minas Gerais, um quadro econômico-demográfico estanque para o século XVIII, posto que era comum as famílias se enveredarem por diversas atividades econômicas ao mesmo tempo, tais como a mineração, a agricultura e comércio. Daí a existência de unidades produtivas multifacetadas, coexistindo a extração de minerais, a produção de gêneros de subsistência e a pecuária. Além disso, com a expansão das áreas mineradoras, as relações de mercado entre essas regiões e os núcleos de população mais antiga intensificaram-se, de maneira que antigas trilhas indígenas e sertanistas ganharam nova importância. Tanto negociantes, tropeiros, sertanistas como simples viajantes passaram a circular em tais caminhos com a frequência cada vez maior, contribuindo dessa forma para que as áreas adjacentes a essas estradas fossem ocupadas, geralmente por roceiros, rancheiros e donos de estabelecimentos como estalagens e pousos. Isso contribuiu para o povoamento e a articulação das áreas intermediárias dos caminhos, uma vez que as atividades ali estabelecidas se relacionavam com o abastecimento das regiões mineradoras, com o fornecimento de abrigo para tropeiros e viajantes. Assim como já ocorrera em Minas Gerais, as estradas e caminhos para as minas goianas tornaram-se eixos de ocupação das áreas dos chamados "sertões", por meio do estabelecimento de pousos e arraias, mesmo que esses propiciassem lucros de pouca monta, fornecendo apenas o necessário para a sobrevivência de seus habitantes. ${ }^{53}$

No início de 1773, o recém-empossado governador de Goiás, José de Almeida e Vasconcelos de Soveral e Carvalho, resolveu visitar os arraiais goianos para tomar conhecimento da situação da Capitania. Durante a viagem, observou que o serviço das lavras, em virtude dos pequenos jornais e da falta de braços, estava pouco desenvolvido, quando não estagnado. A solução adotada pelo governador foi estimular os moradores dos arraiais a descobrirem novas minas nos vastos sertões ainda desconhecidos, especialmente aqueles situados no vale do 
Araguaia. Em vista disso, bandeiras foram organizadas para os diferentes distritos da Capitania, mas quase todas malograram. A bandeira para Meia Ponte, por exemplo, que ficou sob comando do capitão Francisco Soares de Bulhões e do seu ajudante Tomaz de Souza, prosseguiu em direção à campanha do Sul, em busca do Rio Rico. Sem resultados expressivos, a bandeira exauriu recursos de Bulhões. A bandeira para Pilar foi ainda menos bem-sucedida. Seguindo pela margem ocidental do Tocantins em direção à Pontal, a bandeira deparou com os povos Xavante na margem do ribeirão das Almas. $\bigcirc$ conflito resultou na morte do seu comandante, o capitão Maximiano. ${ }^{54}$

José de Vasconcelos saiu do governo da Capitania de Goiás em 1778, quando a entregou ao ouvidor Antônio José Cabral de Almeida. Embora tenha deixado um relato de suas atividades na Capitania, o ex-governador pouco versou sobre Pilar. Observou, apenas, que na localidade ajudou a formar uma companhia de homens pardos e que essa se encontrava fardada e com "bastante adiantamento". Por ato de 20 de abril de 1778 foram marcados os limites de Vila Boa, Crixás, Pilar, Traíras, S. Félix, Conceição, Natividade, Arraias, Cavalcante, Santa Luiz, Meia Ponte, Santa Cruz e Rio das Velhas. ${ }^{55}$

A presença maciça de povos indígenas na região fez que a administração colonial instalasse nas proximidades de Pilar, em 1764, a aldeia de Pedro III do Carretão, composta majoritariamente por Xerente e Xavante. O auge da aldeia se deu no fim da década de 1770, quando cerca de 3 mil xavantes foram fixados em Carretão. De acordo com o frei Estevão Gallais, a aldeia chegou a contar com 10 mil homens, número que nos parece exagerado, no final do século XVIII. ${ }^{56}$ No início do século XIX, todavia, a maior parte dos indígenas aldeados fugiu e passou a investir contra os centros urbanos da região, como Pilar, Amaro Leite e Crixás, prática que também foi levada a cabo por outros povos nativos, em particular os canoeiros. Ao percorrer o julgado de Pilar em 1823, Victor Coelho de Almeida descreveu o Carretão como estando "em ruínas". 57

Parte significativa do ouro explorado durante todo o século XVIII nas Minas Gerais, Goiás e Mato Grosso foi prospectada por meio de técnicas introduzidas pelos africanos e pouco conhecidas pelos europeus. ${ }^{58}$ Há poucas informações, entretanto, dentro da documentação e bibliografia consultadas, sobre as técnicas e procedimentos de mineração utilizados em Pilar nos séculos XVIII e XIX. De acordo com Pizzarro e Araújo, as lavras mais ricas ficavam no "Morro do Pilar", de modo que a grande dificuldade em minerar naquelas paragens era adquirir água em abundância, processo que era feito por meio de bicames. Apesar de reconhecer o potencial aurífero do local, o monsenhor acreditava que o mau uso dessa infraestrutura prejudicou a mineração local. ${ }^{59}$ Johann Baptist Emanuel Pohl, médico, geólogo e botânico austríaco que visitou Pilar e cercanias na mesma época que Araújo, notou que para minerar na serra do Muquém foi necessário efetuar uma complicada obra de engenharia. Esta consistia, basicamente, em levar a água necessária para a mineração por meio de canais. 60
54. Alencastre (1979, p. 194).

55. Alencastre (1979, p. 216).

56. Cunha (1992, p. 400-408).

57. Castro (1996, p. 40). Sobre a questão indígena em Goiás no século XVIII, ver Rocha (1998) e Marcondes (2011).

58. Paiva (2002).

59. Araújo (1820, p. 80).

60. Castro (1996, p. 37-38). 
61. Carta (1762, doc. 1695).

62. Requerimento (1775, doc. 1697).

63. Ofício (1752, doc. 544).

64. Carta (1741, doc. 750$)$.

65. Ofício (1752, doc. 531).

66. Carta (1752, doc. 1140).

67. Coutinho (1797).

68. Salles (1992, p. 262-263).

69. Carta (1762, doc. 1696).
Ao longo do século XVIII a arrecadação do ouro gerou conflitos de interesse em Pilar. Em 1762, em carta endereçada ao rei português D. José, os juízes do julgado de Pilar criticaram os exorbitantes emolumentos que levava o vigário daquela matriz. ${ }^{61}$ Naquele ano os mesmos juízes relataram sobre o "grande vexame" que padeciam os moradores do arraial com os procedimentos abusivos dos contratadores dos dízimos. ${ }^{62}$ Anos antes, o secretário de Estado da Marinha e Ultramar, Diogo de Mendonça Corte Real, fora comunicado pelo intendente de Pilar que um escravo do padre António Rodrigues Posso, chamado Vitoriano, produzia ouro falso. ${ }^{63}$

O ouro extraído em Goiás seguia para alguma das duas casas de fundição da Capitania: a de Goiás, situada na capital, e a de São Félix. Para chegar a esta última, o ouro pilarense podia trilhar dois caminhos. $\bigcirc$ primeiro começava em Pilar e seguia para o norte, até atingir Amaro Leite. De lá seguia sentido nordeste, passando por Correolo e Caldas, até chegar em São Felix. $O$ segundo, mais longo, saía de Pilar, passava por Traíras e pequenos arraiais até atingir o destino final. Se o destino fosse Vila Boa, o carregamento de ouro caminhava sentido sul e passava por Guarinos e Pedro III do Carretão, até chegar na capital goiana. $\bigcirc$ escoamento do ouro da Capitania de Goiás pela Bahia era visto como preferível por algumas autoridades coloniais. Em 1741, o governador e capitão-general de São Paulo, D. Luís de Mascarenhas, comunicou ao rei $D$. João $V$ sobre a facilidade de se remeter o ouro da Fazenda Real pelo caminho da Bahia. ${ }^{64}$ Não se pode dizer com precisão qual era o percurso do ouro goiano, mas o fato é que parte dele era escoada pelo Norte e Nordeste da Colônia. Em 1752 o intendente do ouro de Goiás informou o secretário de Estado da Marinha e Ultramar que alguns mineradores do arraial teriam que encaminhar o ouro extraído de Pilar para a casa de fundição de Vila Boa, uma vez que não havia mais prazo para remetê-lo à Bahia. ${ }^{65} \bigcirc$ transporte do ouro em pó causou problemas à administração da Colônia, que se via às voltas com altos índices de contrabando. Em 1752, em carta ao rei português D. José, o intendente e provedor da Capitania de Goiás, Anastácio da Nóbrega, solicitou que tal procedimento fosse proibido, e que se confiscasse todo o ouro em pó que viesse dos "sertões". 66 A julgar pela documentação de época, ${ }^{67}$ é provável que - escoamento do ouro por saídas diversas tenha estabelecido laços mercantis entre Pilar de Goiás e outras regiões da América portuguesa, sobretudo do norte, contribuindo para a dinamização do comércio intercapitanias, quadro que se torna mais nítido no início do século XIX.

A extração do ouro em Goiás teve seu auge nos anos 1760-1770.68 Na década de 1760, com os lucros auferidos pela extração do ouro de Pilar, as autoridades locais começaram a pleitear por melhorias no arraial. Em 1762, os juízes do julgado de Pilar solicitaram ao rei $\mathrm{D}$. José que do rendimento do Conselho do arraial se fizesse uma cadeia e a casa do Conselho latual Casa de Câmara e Cadeia), uma ponte no rio das Almas e o mais que fosse preciso para $\circ$ "a benefício do mesmo arraial e de mais de cinco mil pessoas do seu distrito". ${ }^{69} \mathrm{~A}$ 
vida cultural de Pilar também se complexificou. No Diário da Visita Geral da Capitania de Goiás (1773), o ajudante de ordens do governo Tomás de Sousa narrou a existência de um teatro público no arraial de Pilar, na ocasião da visita da autoridade máxima goiana àquela paragem: "Estes moradores festejaram a Sua Excelência nas noites de sua estada neste Arraial com duas encamisadas muito lustrosas, e duas óperas que representam em teatro público, com excelentes figuras, com muito luzimento".70

Um dos aspectos mais controversos com relação ao período minerador setecentista de Pilar diz respeito à mão de obra ali empregada. Em sua passagem pela vila no início da década de 1840, o francês Francis Castelnau afirmou que Pilar possuíra outrora cerca de 9 mil escravos, ${ }^{71}$ cifra evidentemente inflacionada, uma vez que o número de homens livres nunca ultrapassou as 5 mil almas naquela localidade. $\bigcirc$ montante de 9 mil escravos só foi atingido por Vila Boa, capital da província, conforme censos oficiais de escravos levantados por Cristina Moraes. ${ }^{72}$

Os dados apresentados pela autora merecem algumas ponderações. Em primeiro lugar, os números referentes ao censo de 1783 devem ser relativizados, uma vez que a quantidade ali contida, 17.713 cativos para toda a Capitania, é muito baixa e destoa dos anos imediatamente posteriores. ${ }^{73}$ Seis anos depois, o censo de 1789 registrou um aumento na população de escravos para 37.309. Nesse censo Pilar surge com 1.967 escravos, abaixo de Crixás, Santa Luzia, Meia Ponte e Vila Boa. $\bigcirc$ censo de 1792 indica o maior número de escravos já documentado para a Capitania de Goiás: 38.533 cativos. Enquanto houve uma redução no número de cativos em Vila Boa e Santa Luzia, Pilar assistiu a um acréscimo de cerca de 2 mil escravos, o que sugere um incremento na extração de ouro naquela localidade. A descoberta das minas do rio das Velhas, posteriormente anexadas ao território mineiro, levou para aquela região mais de 2 mil escravos. $\bigcirc$ censo de 1804 mostra uma tendência decrescente no número de escravos na Capitania, fenômeno que está associado ao declínio geral da exploração aurífera em Goiás.

Os africanos que eram direcionados à Capitania de Goiás entravam na América portuguesa por diferentes localidades, especialmente Belém, São Luís, Salvador e Rio de Janeiro. ${ }^{74}$ Parte dos escravos que chegava a Pilar provinha do chamado Caminho do Sertão, o qual ligava o sertão baiano à Capitania de Goiás. $\bigcirc$ caminho tinha início na Cachoeira do Moritiba, atual município baiano de Cachoeira, e passava por Pedra Redonda, Boa Vista, Morrinhos, Palma, Olhos d'Água, Almas, Sincurá, Carvalho, Vila Nova das Contas, Tapera do Tenente, Quebradas, Lagoa de João Marques, Possoins, Pau d'Espinho, Curralinho, Fazenda do Riacho, Arraial da Carinhanha, Toque-Lambô, Sítio do Meio, Presídio, Vareda do Fogo, Forquilha, Saco do Taquari e Formoso, na fronteira de Pernambuco com Goiás. De Formoso o caminho percorria Santa Maria, Feijoal, Águas Claras, Bandeirinhas, Contagem de São João das Três Barras latual região do Distrito Federal), Vendinha, Mamoeiras, Meia Ponte, Lagoa Grande e, por fim, Vila Boa.
70. Diário (1773, p. 17).

71. Castelnau (1949, p. 22).

72. Moraes (2007, p. 202).

73. Karasch (1996).

74. Moraes (2007, p. 202). 
75. Bertrand (1997, p. 74)

76. Relação (1748).

77. McCreery (2006, p. 186).

78. Soares (2011, p. 3).

79. Araújo (1820, p. 80).

80. Gomes (1825).

81. Atas (1978, p. 102).
O percurso demorava de 40 a 50 dias para ser feito, totalizando 345 léguas. ${ }^{75}$ Pelos Registros de Três Barras e Pé de Serra entravam escravos, gado, cavalgaduras, couros, carne-seca, sal, peixes e outros produtos do sertão:

Por este Registro [Três Barras] entra o comercio de fazenda, e escravos que da cidade da Bahia vem para esta vila, para as Minas da Meia-Ponte, e ainda para as de Pillar e Crixás; por ele entram também os gados, cavalgaduras, carnes secas que vem do sertão para as ditas Minas, e também algum gênero de negócio do mesmo Sertão; como é o sal, vulgarmente chamado da Terra, e alguns couros de veado, e peixe dos Rios do mesmo Sertão [...] Desta vila ao Registro do Pé da Serra que fica no caminho Por ela entra a maior parte do comercio que vem da Bahia e do Sertão para as Minas de Pilar, na mesma forma que passa pelo antecedente das Três Barras: o que vem do Sertão para as Minas de Pillar, e Crixás são cinqüenta léguas. ${ }^{76}$

No início do século XIX, Pilar contava com cerca de 4 mil almas, sendo quase a metade delas escravos, o maior percentual de toda a província - $47 \%$ do total de habitantes. Mesmo com o declínio da exploração aurífera, a posse de escravos permaneceu como uma das características das localidades mineradoras goianas no início do Oitocentos, embora a tendência fosse de diminuição do número de cativos. ${ }^{77}$ Composta majoritariamente por pretos e pardos livres, a Pilar do começo do Oitocentos somava poucos brancos, menos de $20 \%$, segundo o censo de $1804 .{ }^{78}$ Segundo Pizarro e Araúio, que transitou pela região no início do século XIX, em fins da década de 1810 Pilar contava cerca de "500 fógos ou mais", além de "5.000 almas sujeitas a Sacramentos".79 Às vésperas da Independência, o quadro populacional sofreu mudanças em relação ao início do século. Segundo a Estatística da Província de Goiás (1825), o número de escravos caiu para cerca de 1100, enquanto que o total de livres aumentou, excedendo 2000 pessoas. ${ }^{80}$ Os motivos desse decréscimo são diversos: declínio na produção aurífera, aumento das taxas de alforria e êxodo de proprietários com maior número de escravos.

Com a instauração do Império do Brasil, fez-se cada vez mais necessário erigir um aparato jurídico-administrativo que desse sustentação ao novo Estado, de forma que a reordenação das administrações provinciais constituiu um dos marcos desse processo. Em 1831, a Regência sancionou a proposta do Conselho Geral da Província de Goiás, a qual tornava vilas os arraiais de Traíras, Cavalcanti, Porto Imperial e Pilar. ${ }^{81}$ Dois anos depois o Conselho Geral da Província de Goiás tomou a resolução, mais tarde aprovada pela Assembleia Geral, a qual dividia a província em quatro Comarcas. A partir daí Pilar passou a fazer parte da Comarca de Goiás, junto com as vilas de Jaraguá, Meia Ponte, S. José do Tocantins e Traíras.

Após o Ato Adicional (1834), quando da abertura da primeira legislatura da Assembleia goiana, em 1835, o presidente Jose Rodrigues Jardim fez um arrazoado sobre a situação da província, prática que se tornaria comum nos anos seguintes em todas as localidades do Império. Sobre Pilar, Rodrigues Jardim apontou para a necessidade de dinamização da estrutura de transportes daquela vila, que 
sofria nos períodos chuvosos. ${ }^{82}$ Além disso, a estrada que ligava Pilar a Porto Imperial via Amaro Leite era, segundo o presidente, uma das "mais interessantes" da província, posto que por ela era possível transportar sal, vinhos, aço, chumbo e "os mais gêneros" que ali desembarcavam "importados da Província do Pará" e depois tinham como destino final a capital goiana. Esse trecho da fala de Rodrigues Jardim mostra como a região de Pilar era vista como estratégica nas relações comerciais, feitas por rede fluvial, entre Goiás e Pará, o que ajuda a relativizar um pouco a ideia da decadência pós-ciclo do ouro. Três anos mais tarde a presidência da província encarregou José Renovado de construir sete pinguelas na estrada de Pilar para Amaro Leite. ${ }^{83}$

A discussão em torno do potencial viário de Pilar seria retomada anos depois, tornando-se um tópico recorrente na fala das autoridades goianas. Para Antonio Candido da Cruz Machado, que governou a província no fim da década de 1850, Pilar situava-se num lugar geograficamente estratégico dentro da malha fluvial goiana, iá que ela estava incrustada na entrada dos vales do Tocantins, via rio das Almas, e do Araguaya, via rio Crixás. Para o coronel, Pilar deveria ser entendida como "a chave dos terrenos mais povoados compreendidos entre o caminho da capital e essa Vila", bem como entre as margens do rio Maranhão até a confluência do rio das Almas, local onde os índios apareciam para repousar nos limites da "immensa matta". Desse modo, deveria ser permanentemente ocupado por destacamentos em virtude do fácil acesso que os índios canoeiros tinham do local. Pilar seria, também, o ponto limite sul, de uma possível navegação que articularia o rio Tocantins às barras dos rios Maranhão e das Almas. Provável porque os "obstáculos aumentados pela diminuição do volume das águas" demandavam "trabalhos tão grandes" que somente poderiam ser empreendidos em vista das "futuras vantagens oferecidas pela navegação deste ponto ao Para". Ainda na ótica do coronel Cruz Machado, devia-se ocupar o norte de Pilar, região conhecida como Genipapo, onde a "uberdade do solo, e as abundantes matas" permitiriam aos colonos e soldados "obter facilmente víveres". Ademais, os "raros habitantes desse lugar" teriam asseguradas suas propriedades cada vez mais "restringidas pelos ataques quotidianos dos índios canoeiros", que utilizavam esse local como paragem para a passagem para o outro lado do rio Maranhão ou para as terras dispostas na margem esquerda, a leste de Pilar. Por fim, Cruz Machado acreditava que o território de Amaro Leite, cujas "matas e campos" eram de "extraordinária fertilidade, e com grande extensão", merecesse um adensamento em seu povoamento. ${ }^{84}$

Aos poucos Pilar e suas imediações iam ganhando novos contornos. Em 1835 criou-se o distrito de Amaro Leite, o qual foi incorporado ao município de Pilar. No mesmo ano instituiu-se uma linha de correio entre Pilar e Amaro Leite. No ano seguinte foi criada uma escola de primeiras letras no julgado de Crixás. ${ }^{85}$ Com o passar dos anos, a administração provincial intensificou seus trabalhos relativos à mensuração da população goiana. Em 1837, a junção das paróquias de Pilar, Crixás, Traíras e São José contava 10.852 habitantes. ${ }^{86}$ 
87. Castelnau (1949, p. 22).

88. Discurso (1838, p. 22-23).

89. Gomes (1825).

90. Cunha (1992, p. 408).

91. Relatorio (1847, p. 14).

92. Falla (1850, p. 7-8), Relatorio (1852, p. 7), Relatorio (1854, p. 28).

93. Relatorio (1858), Relatorio (1862, p. 116).

94. McCreery (2006, p. 204).

95. Relatorio (1862, p. 10222). Ver, também, Taunay (1876, p. 60).

96. Funes (1986).

97. Relatorio (1873).
Ao transitar por Goiás em 1843, o naturalista francês Francis de Castelnau notou que a vila de Pilar era "muito edificada", e que as paredes das casas eram "de pedra e cobertas de telha". ${ }^{87}$

Uma questão importante, entretanto, permanecia sem solução: o confronto com os povos indígenas, sobretudo com os Canoeiro e Xavante, temática essa que perpassou os relatórios oficiais das décadas de 1830-50, os quais indicavam que grupos de nativos continuam penetrando nos distritos de Amaro Leite e São Felix, dirigindo as suas carreiras desde o município de São José de Tocantins até o rio da Cana Braba. ${ }^{88}$ Segundo a documentação oficial, os confrontos com indígenas atravancavam o desenvolvimento das fazendas de criação de gado, que outrora "deram avultadas vantagens" para Pilar, especialmente do distrito de Amaro Leite. A fim de sanar o problema, os presidentes sugeriam lançar mão de uma nova política de aldeamentos. Vale notar, nesse sentido, que a aldeia de Pedro III do Carretão, por exemplo, contava em 1825 com cerca de 200 índios ${ }^{89}$ e, em 1849, com não mais que 80 , os quais eram obrigados a plantar alimentos para 0 consumo próprio e para os viajantes que passavam pela estrada que ligava a cidade de Goiás a Pilar. ${ }^{90} \mathrm{Na}$ ótica do executivo provincial, a "civilização dos índios" só seria obtida caso os aldeamentos fossem instituídos nos próprios locais onde eles viviam, pois assim eles se convenceriam, aos poucos, do caráter positivo da missão civilizadora, o que os tornaria mais sociáveis. ${ }^{91}$ Durante a década de 1850, as autoridades atribuiriam à "melhoria no patrulhamento da região" o declínio nas investidas dos "selvagens", o que pode ser lido como um aumento no uso da violência contra os povos indígenas. ${ }^{92}$

Em meados do século XIX, a vila de Pilar cultivava algodão, fumo e trigo, produtos que eram exportados pelo rio Tocantins para a província do Pará, ou até mesmo para a Corte pela estrada de Minas Gerais. No que tange à produção para consumo local, havia lavouras de milho, feijão, arroz, fumo e mamona, além de fazendas de criação de animais, como gado vacum, cavalar e suínos. Com relação à indústria e às manufaturas, contava com teares, engenhos de cana, alambiques, rodas de mandioca (farinha), moinhos (fabrico de fubá), monjolos (farinha de milho), 10 curtumes (produção de solas e peles), além algumas "queijeiras" para a fabricação de queijos e requeijões. ${ }^{93}$ A agricultura familiar desempenharia um importante papel na economia regional no período. Era comum que famílias sem escravos ganhassem a vida vendendo milho, feijão, mandioca, açúcar e algodão. ${ }^{94}$ A extração mineral, embora sem o destaque de outrora, ainda permanecia como atividade econômica de relativa importância. ${ }^{95}$

A segunda metade do século XIX marca, em termos gerais, um momento de aceleração na então lenta e gradual transição da economia mineradora - ou da sua preponderância - à agropecuária em Goiás. ${ }^{96}$ Da sua parte, Pilar de Goiás presenciou um esvaziamento populacional ${ }^{97}$ que revela um quadro de reajuste socioeconômico e demográfico de uma vila que, como alternativa e/ou complemento à declinante mineração, forjou uma sociedade predominantemente rural, baseada na agricultura de gêneros de primeira necessidade e na pecuária. 
contato comercial com paragens distantes - a exemplo de Tocantins, Pará, Rio de Janeiro e Minas Gerais - se enfraqueceu no final do século, na medida em que se sedimentou uma sociedade cada vez mais voltada para o cenário microrregional. Adentrado o século XX, tal realidade seria tensionada esporadicamente, na dependência de novos surtos mineradores.

Conclusão: Pilar de Goiás, a materialidade e a história

Retornemos à atual Pilar de Goiás. Pouco mais de uma dezena de ruas e travessas, arruamento irregular, alguns exemplares do patrimônio tombado restaurados - Casa de Câmara, as duas igrejas -, outro tanto em condição precária, como o próprio museu. Uma população que, não fosse a atividade mineradora recém-reativada, mantém uma economia fundamentada em pequenas propriedades rurais, muito diversificadas, espalhadas ao redor do centro urbano e à beira das estradas, interligadas por uma complexa rede de caminhos antigos. Da antiga mineração, do século XVIII e início do XIX, o que restou ainda está por ser recuperado ao Cerrado, o qual lentamente o engoliu.

Nenhuma estrutura monumental foi encontrada pelas pesquisas arqueológicas - ainda em encerramento. Nenhuma construção que denunciasse - gigantismo prometido pela impressionante quantidade de escravos que supostamente habitaram a vila no seu ápice de produção (9 mil indivíduos). Não há um único cemitério condizente com essa quantidade de pessoas, livres ou não. Nada de grandes áreas de moradia para além do núcleo da cidade, sobretudo do complexo tombado, tido como remanescente do apogeu minerador. Poucos objetos coloniais resgatados, dos quais a grande maioria é oriunda dos surtos minerados do século XX.

As conclusões da arqueologia não têm sido muito boas a esse respeito: insiste-se em um declínio tão rápido, tão profundo, que teria apagado a materialidade dessa cultura, desse capítulo da história, como se tivesse entrado em um buraco negro e sido completamente eliminado do universo. Ou, senão, especula-se que ainda não se encontrou o lugar certo e algo ainda está escondido sob a terra.

Quiçá esteja aí uma das causas da longevidade do discurso apologético/decadentista sobre a sociedade goiana e, especificamente, sobre Pilar de Goiás. A falta de vestígios materiais que permitam reconstruir uma idade de ouro mineradora, quando confrontada à fala pessimista, mas ao mesmo tempo saudosa dos agentes históricos, gera um nó que somente é desfeito com o uso do contraste auge-decadência. É como se incoerências e contradições se dissolvessem em prol de um discurso pretensamente mais homogêneo e, por que não, mais objetivo. No entanto, o que se vê é o efeito contrário: uma armadilha que ainda captura historiadores, arqueólogos e memorialistas. Ao endossarem discursos forjados no passado por administradores públicos, viajantes e outros protagonistas, em vez de questioná-los e entendê-los como vozes dotadas de 
interesses e desígnios específicos do seu tempo, muitos trabalhos acabam acrescentando mais uma trama no tecido da memória, que se perpetua com novo vigor e dificulta ainda mais a análise histórica.

O mais óbvio e consistente seria concluir, portanto, que o desenho, a interpretação dessa sociedade e de sua expressão material estava equivocada, ou correta, para os caminhos da memória e da representação social. Não se pode encontrar algo que não existiu.

Ainda que saibamos menos do que gostaríamos a respeito dessa sociedade, por mais que o caminho da pesquisa histórica ainda seja longo e, de certo modo, interminável, temos sim informações suficientes para estabelecer um desenho mais claro e realista, como pudemos verificar.

Uma sociedade multifacetada, plástica e dinâmica em suas conformações - parte disso em função das características do universo minerador -, arranjos econômicos diversificados, compostos da atividade mineradora, comércio e abastecimento, agricultura e pecuária.

Pilar de Goiás deve ser compreendida não como uma majestática cidade do ouro, coisa que efetivamente não foi, de modo que sua riqueza e importância residem nas possibilidades que seu surgimento e trajetória oferecem à pesquisa histórica: a compreensão mais clara do processo de ocupação da parcela central da Colônia, territórios que ainda no século XX representavam um desafio à colonização, o entendimento das dinâmicas demográficas e econômicas das populações residentes nas frentes colonizadoras, as chamadas "bocas dos sertões", a constituição e o funcionamento das redes de comércio, de abastecimento e do trânsito de pessoas no coração da América do Sul, a dinâmica cultural desses universos, suas composições. Dada a relativa escassez de documentação, se comparada a outras regiões da Colônia, os estudos da cultura material representam substancial aporte às pesquisas. Desde que o caminho de interpretação dessa cultura material seja o da investigação histórica; a memória, se contemplada, deve ser necessariamente mediada, para que inclusive tenhamos consciência das convergências e dos limites entre ela e a história.

Talvez as pesquisas sobre a história e a cultura material de Pilar de Goiás, associadas à sua trajetória mineradora, até agora, possam nos relembrar a figura clássica da procura de um gato negro em quarto escuro que não está lá. E, no caso de Pilar de Goiás, que sequer esteve algum dia. 


\section{REFERÊNCIAS}

FONTES MANUSCRITAS

Arquivo Central do Iphan (Rio de Janeiro) - Acervo Noronha Santos

PROCESSO de tombamento da cidade de Pilar de Goiás. No do processo: 0458-T-52.

Arquivo Histórico Estadual de Goiás (Goiânia/GO)

REGISTRO de Requerimentos de cartas de sesmarias (1732-1754). Cx. 984.

REGISTRO de Requerimentos de cartas de sesmarias (1754-1759). Cx. 985.

REGISTRO de Requerimentos de cartas de sesmarias (1760-1765). Cx. 986.

REGISTRO de Requerimentos de cartas de sesmarias (1754-1795). No 0008.

Arquivo Histórico Ultramarino - Projeto Resgate

CARTA do intendente e provedor da capitania de Goiás, Anastácio da Nóbrega, ao rei [D. José], sobre a importância de se proibir o transporte de ouro em pó; a confiscação de todo o ouro em pó que venha dos sertões e acerca das medidas severas contra o contrabando. Goiás, documento 1140, 24/03/1752.

CARTA do intendente e provedor da Fazenda Real de Goiás, Anastácio da Nóbrega, ao rei [D. José], remetendo mapas do rendimento da Casa de Fundição de Goiás em 1751 e sobre o estabelecimento do novo método da capitação e conferência do ouro. AHU-ACL-N-Goias, $N^{\circ}$ Catálogo: 577, 31/05/1753.

CARTA do [governador e capitão-general de São Paulo], D. Luís de Mascarenhas, ao rei [D. João V], sobre o florescimento dos novos descobertos nas Minas de Goiás, ao norte de São Paulo, entre eles os de Arraias e Rio do Sono, e acerca da facilidade de se remeter o ouro da Fazenda Real pelo caminho da Bahia. Goiás, documento 750, 10/02/1741.

CARTA dos juízes do julgado de Pilar, ao rei [D. José], sobre os exorbitantes emolumentos que leva o vigário daquela matriz e relatando as grandes somas que os vigários do lugar levavam no tempo em que as minas produziam muito ouro. Goiás, documento 1695, 24/03/1762.

CARTA dos juízes de julgado de Pilar, ao rei [D. José], solicitando que do rendimento do Conselho do arraial do Pilar se faça cadeia e Casa do Conselho, ponte no rio das Almas e o mais que for preciso a benefício do mesmo arraial e de mais de cinco mil pessoas do seu distrito. Goiás, documento 1696, 24/03/1762. 
CARTA dos juízes do julgado do Pilar, ao rei [D. José], sobre o grande vexame que padecem não só os moradores do arraial mas também os de toda a capitania com os procedimentos abusivos dos contratadores dos dízimos. Goiás, documento 1697, 24/03/1762.

OFÍCIO do intendente do arraial do Pilar, Anastácio da Nóbrega, ao [secretário de estado da Marinha e Ultramar], Diogo de Mendonça Corte Real, sobre terem passado guias do ouro extraído em Janeiro, acerca do qual deveria ser cobrado o quinto, e a devassa que levantou no arraial do Pilar, descobrindo que um escravo do padre António Rodrigues Posso, de nome Vitoriano, produzia ouro falso. AHU-ACL-N-Goias, $N^{\circ}$ Catálogo: 544, 30/07/1752.

OFíCIO do intendente do Ouro de Goiás, Anastácio da Nóbrega, ao [secretário de estado da Marinha e Ultramar], Diogo de Mendonça Corte Real, sobre João de Sousa Machado, Domingos Pereira, António da Costa Pinheiro, Manuel Ferreira Dilar e o padre António Rodrigues Posso, terem lhe solicitado recebesse o ouro na Casa de Fundição de Vila Boa, por não terem prazo para levá-lo à Cidade da Bahia, para onde lhes foram passadas as guias pela Intendência e Comissaria do arraial do Pilar, e acerca de não ter consentido nesse pedido. AHU-ACL-N-Goias No Catálogo: 531, 16/05/1752.

RELAÇÃO de Contagens, ou Registros, que tem o Contrato das Entradas nos Continentes desta Capitania, e suas circunferências, e das distancias que há nessa Vila, de uns, e outros, e ais arraiais da Comarca. Mato Grosso, Caixa 39, documento 51, 1748.

REQUERIMENTO do vigário da freguesia do arraial do Pilar, António Fraga de Meireles, ao rei [D. José], solicitando provimento para fazer execução nos bens dos fregueses que não se ocupam do exercício de minerar, pelas quantias que lhe devem de direitos paroquiais, na mesma forma que faziam seus antecessores. Goiás, documento 1697 , $27 / 03 / 1775$.

Biblioteca Nacional (Rio de Janeiro) - Seção de Manuscritos

COUTINHO, Francisco de Souza. Ofício a Rodrigo de Souza Coutinho enviando as informações sobre os meios de promover e facilitar a navegação e o comércio da capitania do Pará com a de Goiás. 6/8/1797 (07, 03, 041).

GOMES, Caetano Maria Lopes. Estatística da província de Goiás. 1825. (11, 4, 002).

Biblioteca Geral da Universidade de Coimbra (Portugal) - Seção de Manuscritos

DIÁRIO $1^{\circ}$ da Jornada, que do Porto da cidade do Rio de Janeiro fes o Excellentissimo General e Cappitam Governador de Goyaz Joze de Almeida de Vasconcellos de Soveral e Carvalho, para Villa boa da Capial do mesmo Governo a constituir-se na posse delle. Por Thomás de Souza, Ajudante do Governo Referido, 1773. (Ms. 1596). 


\section{FONTES IMPRESSAS}

Arquivo Nacional (Rio de Janeiro) - Biblioteca, Seção de Obras Raras

BREVE reflexão sobre o meio eficaz de se remediar a decadência da Capitania de Goiás. Revista do Instituto Histórico e Geográfico Brasileiro, 55, pt.1, 1892, 399-402.

DISCURSO com que o presidente da provincia de Goyaz fez a abertura da primeira sessão ordinaria da segunda legislatura da Assembléa Provincial no 1.o de julho de 1837. Goyaz, Typ. Provincial, 1837.

DISCURSO com que o presidente da provincia de Goyaz fez a abertura da primeira sessão ordinaria da segunda legislatura da Assemblea Provincial no 1.o de julho de 1838. Goyaz, Typ. Provincial, 1838.

DISCURSO com que o vice-presidente da provincia de Goyaz fez a abertura da primeira sessão ordinaria da quinta legislatura da Assemblea Provincial no 1.o de junho de 1843. Goyaz, Typ. Provincial, 1843.

FALLA que recitou o presidente [sic] da provincia de Goyaz, o doutor Eduardo Olimpio Machado, n'abertura da Assemblea Legislativa da mesma provincia em o 1.o de maio de 1850. Goyaz, Typ. Provincial, 1850.

RELATORIO que à Assemblea Legislativa de Goyaz apresentou na sessão ordinária de 1835 o Exm. Presidente da mesma Província Jose Rodrigues Jardim. Meyaponte: Tipografia Provincial, 1835.

RELATORIO que à Assemblea Legislativa de Goyaz apresentou na sessão ordinaria de 1836 o exm. presidente da mesma provincia, Jozé Rodrigues Jardim. Goyaz, Typ. Provincial, 1844.

RELATORIO que á Assembléa Legislativa de Goyaz apresentou na sessão ordinaria de 1839 o exm. presidente da mesma provincia, d. Joze de Assiz Mascarenhas. Goyaz, Typ. Provincial, 1839.

RELATORIO que á Assembléa Legislativa de Goyaz apresentou na sessão ordinaria de 1840 o exm. presidente da mesma provincia, d. Joze de Assiz Mascarenhas. Goyaz, Typ. Provincial, 1840.

RELATORIO que á Assemblea Legislativa de Goyaz apresentou na sessão ordinaria de 1841 o exm. vice-presidente na mesma provincia, Joze Rodrigues Jardim. Goyaz, Typ. Provincial, 1841.

RELATORIO que á Assemblea Legislativa de Goyaz apresentou na sessão ordinaria de 1842 o exm. vice-presidente da mesma provincia, Francisco Ferreira dos Santos Azevedo. Goyaz, Typ. Provincial, 1842.

RELATORIO que á Assembléa Legislativa de Goyaz apresentou na sessão ordinaria de 1845 o exm. presidente da mesma provincia, dr. Jose de Assiz Mascarenhas. Goyaz, Typ. Provincial, 1845. 
RELATORIO que á Assemblea Legislativa de Goyaz apresentou na sessão ordinaria de 1846 o exm. presidente da mesma provincia doutor Joaquim Ignacio Ramalho. Goyaz, Typ. Provincial, 1846.

RELATORIO que á Assembléa Legislativa de Goyaz apresentou na sessão ordinaria de 1847 o exm. presidente da mesma provincia, doutor Joaquim Ignacio Ramalho. Goyaz, Typ. Provincial, 1847.

RELATORIO que á Assembléa Legislativa de Goyaz apresentou na sessão ordinaria de 1848 o exm. vice-presidente da mesma provincia, Antonio de Padua Fleury. Goyaz, Typ. Provincial, 1848.

RELATORIO que á Assemblea Legislativa de Goyaz apresentou na sessão ordinaria de 1852 o exm. presidente da provincia, doutor Antonio Joaquim da Silva Gomes. Goyaz, Typ. Provincial, 1852.

RELATORIO que á Assemblea Legislativa Provincial de Goyaz apresentou na sessão ordinaria de 1854 o presidente da provincia, Antonio Candido da Cruz Machado. Goyaz, Typ. Provincial, 1854.

RELATORIO apresentado á Assembléa Legislativa Provincial de Goyaz na sessão ordinaria de 1858 pelo exm. presidente da provincia, dr. Francisco Januario da Gama Cerqueira. Goyaz, Typ. Goyazense, 1858.

RELATORIO apresentado á Assembléa Legislativa Provincial de Goyaz na sessão ordinaria de 1858 pelo exm. presidente da provincia, sr. José Martins Pereira de Alencastre, 1862.

RELATORIO apresentado á Assembléa Legislativa Provincial de Goyaz pelo exm.o sr. dr. Antero Cicero de Assis, presidente da provincia, em o 1.o de junho de 1873. Goyaz, Typ. Provincial, 1873.

Outras fontes impressas

ALENCASTRE, José Martins Pereira de. Anais da provincia de Goiás. Goiânia: Sudeco/Governo de Goiás, 1979. $1^{\text {a }}$ edição: 1864.

ARAÚJO, Jose de Souza Azevedo Pizarro e. Memorias Históricas do Rio de Janeiro e das províncias annexas à jurisdicção do Vice-Rei do Estado do Brasil dedicadas a El-Rei Nosso Senhor D. João VI. Rio de Janeiro: Impressão Régia, 1820.

ATAS do Conselho de Estado (1823-1834). In: RODRIGUES, José Honório (Dir.). Atas do Conselho de Estado: obra comemorativa do sesquicentenário da instituição parlamentar. Brasília: Centro Gráfico do Senado Federal, 1973-1978, 13 v.

CASTELNAU, Francis. Expedição às regiões centrais da América do Sul. São Paulo: Companhia Editora Nacional, 1949. 
FRANCO, Virgílio de Mello. Viagens pelo interior de Minas Gerais e Goiás. Rio de Janeiro: Imprensa Nacional, 1888.

POHL, Joahann Emmanuel. Viagem no interior do Brasil. Tradução: Milton Amado e Eugênio Amado. São Paulo: Edusp, 1976.

SOUZA, Luiz Antônio da Silva e. Memória sobre o Descobrimento, Governo, População e Cousas mais Notáveis da Capitania de Goyaz, 1814. In: TELES, José Mendonça. Vida e obra de Silva e Souza. Goiânia: Editora da UFG, 1998.

LIVROS, ARTIGOS E TESES

ARAUJO, Renata. As cidades da Amazônia no século XVIII: Belém, Macapá e Mazagão. Porto: Faculdade de Arquitectura do Porto, 1998.

BACELlAR, Carlos de Almeida Prado; BRIOSCHI, Lucila Reis (Org.). Na estrada do Anhanguera: uma visão regional da história paulista. São Paulo: Humanitas/FFLCH/USP, 1999.

BERTRAND, Paulo. História geral da capitania de Goiás. Goiânia: Editoras UCG/UFG; Brasília: Solo, 1997.

BORGES, Ana Maria. Patrimônio Histórico de Goiás. Brasília: Ministério da Cultura, 1987.

BORREgO, Maria Aparecida de Menezes. A teia mercantil: negócios e poderes em São Paulo colonial (1711-1765). São Paulo, 2006. Tese (Doutorado em História) -FFLCH/USP.

BOSI, Eclea. Memória e sociedade: lembranças de velhos. São Paulo: Companhia das Letras, 2012.

BUENO, Beatriz Piccolotto Siqueira. Desenho e desígnio: o Brasil dos engenheiros militares (1500-1822). São Paulo: Edusp/Fapesp, 2011.

CASTRO, Onildo de. O julgado de Pilar: resgate histórico. Brasília: Grafisa, 1996.

CHAUL, Nars Fayad. Caminhos de Goiás: da construção da decadência aos limites da modernidade. Goiânia: Ed. UFG, 1997.

CUNHA, Manuela Carneiro da (Org.). História dos índios no Brasil. São Paulo: Companhia das Letras, 1992.

DOLES, Dalísia Elizabeth Martins. As comunicações fluviais pelo Tocantins e Araguaia no século XIX. Goiânia: Editora Oriente, 1973.

; NUNES, Heliane Prudente. Memória da Ocupação de Goiás na Primeira Metade do Século XIX: a visão dos viajantes europeus. In: Ciências Humanas em Revista. Goiânia: Ed. da UFG, 1992. 
DUBUGRAS, Elvin Mackay. Notas sobre a arquitetura do século XVIII em Pilar de Goiás. Brasília: Universidade de Brasília, 1965. Mimeografado.

FUNES, Eurípedes Antônio. Goiás 1800-1850: um período de transição da mineração à agropecuária. Goiânia: Ed. UFG, 1986.

FURTADO, Júnia Ferreira. Homens de negócio: a interiorização da metrópole e do comércio nas Minas setecentistas. São Paulo: Hucitec, 1999.

GRAÇA FILHO, Afonso de Alencastro. A Princesa do Oeste e o mito da decadência de Minas Gerais: São João del-Rei (1831-1888). São Paulo: Annablume, 2002.

GUIMARÃES, Manoel Salgado; RAMOS, Francisco Régis Lopes. Futuro do pretérito, escrita da bistória e bistória do museu. Fortaleza: Instituto Frei Tito de Alencar, 2010.

KARASCH, Mary. Os quilombos do ouro na Capitania de Goiás. In: REIS, João José; GOMES, Flávio dos Santos (Org). Liberdade por um fio. História dos quilombos no Brasil. São Paulo: Companhia das Letras, 1996.

KOK, Glória, O sertão itinerante: expedições da capitania de São Paulo no século XVIII. São Paulo: Hucitec, 2004

LE GOFF, Jacques. História e memória. São Paulo: Editora da Unicamp, 1996.

LIMA, Nei Clara. Narrativas orais: uma poética da vida social. Brasília, 1990. Dissertação (Mestrado) - Departamento de Antropologia, Universidade de Brasília.

MARROU, Henri. Sobre o conbecimento histórico. Rio de Janeiro: Editora Zahar, 1978.

MARCONDES, Javã Isvi Pinheiro (2011). O problema da defesa do território na Capitania de Goiás no século XVIII. Goiânia, 2011. Dissertação (Mestrado) - FH/UFG.

MATTOS, Raimundo José da Cunha. Corografia histórica da Província de Goiás. Goiânia: Editora Líder, 1979.

MAXWELL, Kenneth. A devassa da devassa: a Inconfidência Mineira - Brasil - Portugal (17501808). Rio de Janeiro: Paz e Terra, 2010.

MCCREERY, David. Frontier Goiás, 1822-1889. Stanford: Stanford University Press, 2006.

MEDICCI, Ana Paula. Administrando conflitos: o exercício do poder e os interesses mercantis na capitania/província de São Paulo (1765-1822). São Paulo, 2010. Tese (Doutorado) FFLCH/USP.

MORAES, Cristina de Cássia Pereira. O tráfico de escravos para o Brasil no século XVIII. Revista Brasileira do Caribe, São Luís: UFMA, v. VIII, n. 15, jul./dic, p. 197-243, 2007.

MOURA, Carlos Francisco. Viagem através de Goiás e Mato Grosso em 1772 - O Diário de Viagem do Governador Luís de Albuquerque e a toponímia e a ecologia da Região. Revista do Instituto Histórico e Geográfico de Goiás, Goiânia: IHGG, nº 6, 1977. 
NORA, Pierre. Les lieux de memoire. Paris: Gallimard, 1984.

OLIVEIRA, Cecília Helena de Salles. Entre memória e história: apontamentos sobre a formação do Museu Paulista. In: GUIMARÃES, Manoel Salgado; RAMOS, Francisco Régis Lopes. Futuro do pretérito, escrita da história e história do museu. Fortaleza: Instituto Frei Tito de Alencar, 2010.

Museus de história: o desafio de ver com outros olhos. In: PIRES, Francisco Murari. Antigos e modernos: diálogos sobre a (escrita da) história, São Paulo: Alameda, 2009.

PAIVA, Eduardo França. Bateias, carumbés, tabuleiros: mineração africana e mestiçagem no Novo Mundo. In: PAIVA, Eduardo França; ANASTASIA, Carla Maria Junho (Org.). O trabalho mestiço: maneiras de pensar e formas de viver, séculos XVI a XIX. São Paulo: Annablume; Belo Horizonte: PPGH/UFMG, 2002.

PALACín, Luís. O século do ouro em Goiás. 4. ed. Goiânia: Ed. UCG, 1972. ; MORAES, Maria Augusta. História de Goiás. Goiânia: Ed. Da UCG: 1994.

PESEZ, Jean-Marie. A história da cultura material. In: LE GOFF, Jacques. A história nova. Rio de Janeiro: Martins Fontes, 2003, p. 180-215.

POULOT, Dominique. Museu e museologia. Belo Horizonte: Autêntica, 2013.

Uma bistória do patrimônio no Ocidente, séculos XVIII ao XXI: do monumento aos valores. São Paulo: Estação Liberdade, 2009.

Le musée d'histoire em France entre tradicions nacionales et soucis identitaires. Anais do Museu Paulista. História e cultura material. São Paulo, v. 15, n. 2, p. 293-316, jul-dez 2007.

PROUS, André. Arqueologia brasileira. Brasília: UnB, 1992.

RELATÓRIO Final do Programa Diagnóstico do Patrimônio Histórico, Arquitetônico e Arqueológico de Pilar de Goiás/GO. São Paulo: Zanettini Arqueologia, 2010.

RENFREW, Colin; BAHN, Paul. Archaeology: theories, methods and practice. London: Thames and Hudson, 2008.

RICOEUR, Paul. A memória, a história e o esquecimento. Campinas: Ed. Unicamp, 2007.

ROCHE, Daniel. História das coisas banais: nascimento do consumo séc. XVII-XIX. Rio de Janeiro: Rocco, 2000.

ROCHA, Leandro. O Estado e os índios: Goiás, 1850-1889. Goiânia: Ed. UFG, 1998.

SALLES, Gilka Vasconcelos Ferreira de. Economia e escravidão na Capitania de Goiás. Goiânia: Ed. da UFG, 1992.

SANDES, Noé Freire; ARRAIS, Cristiano Alencar. História e memória em Goiás no século XIX: uma consciência da mágoa e da esperança. Varia bistoria. Belo Horizonte, v. 29, n. 51, p. 847-861, 2013. 
SILVA, Rodrigo. De rios e colinas: a cidade de São Paulo entre os séculos XVI a XVIII. Um estudo sobre a tradição urbanística de origem lusitana e suas transformações à época do Iluminismo. São Paulo, 2016. Tese (Doutorado) - FFLCH/USP.

SILVA, Rogério Chaves da. Reflexões sobre o fazer histórico: uma história da historiografia em (sobre) Goiás (da década de 1920 à de 1990). Goiânia, 2015. Tese (Doutorado) - FH/UFG.

SIMONSEN, Roberto Cochrane. História econômica do Brasil (1550-1820). 8. ed. São Paulo: Editora Nacional, 1978.

SOARES, Márcio de Sousa. Pretos e pardos na fronteira do Império: hierarquias e mobilidade social de libertos na capitania de Goiás (século XVIII). In: IV SEMINÁRIO DE PESQUISA DO ESR. Universidade Federal Fluminense - Polo Universitário Campos dos Goytacases, 2011, p. 1-17.

SOUZA, Laura de Mello e. Os desclassificados do ouro: a pobreza mineira no século XVIII. Rio de Janeiro: Graal, 2004.

TAUNAY, Alfredo de Escragnolle. A província de Goyas na Exposição Nacional de 1875. Rio de Janeiro: Typographia Nacional, 1876.

VEYNE, Paul. Como se Escreve a História. Brasília: UNB, 1982.

WARNIER, Jean Pierre. Construire la culture materielle: l'homme qui pensait avec ses doigts. Paris: Presses Universitaires de France, 1999.

WICHERS, Camila de Moraes; LUSSIM, Beatriz; DIONIZIO, Daniela Rodrigues. Pilar de Goiás entre tempos e narrativas. Rev. Arqueologia Pública, Campinas: Unicamp, v. 9, n. 4(14), p. 293-316, 2015.

Artigo apresentado em 02/1 1/2016. Aprovado em 22/03/2017. 